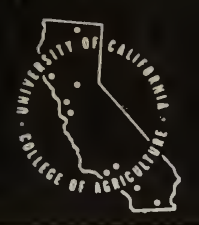

Division of Agricultural Sciences

U N I VER S I T Y OF CALIFOR N I A

1) YOR CALIFORNIA'S MIDDLE ELEVATION DESERT

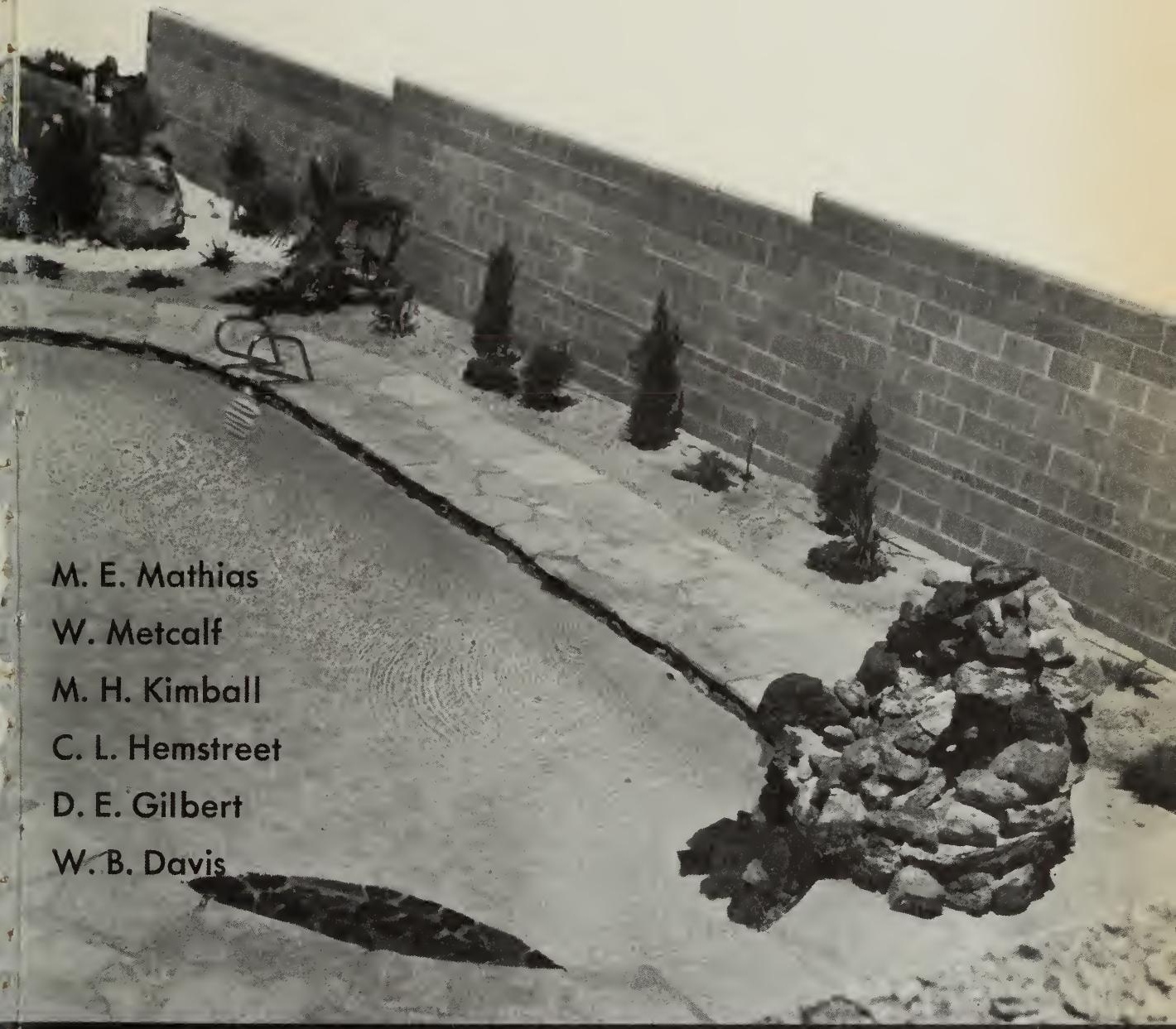

CALIFORNIA AGRICULTURAL EXPERIMENT STATION

BULLETIN 839 
Digitized by the Internet Archive in 2012 with funding from University of California, Davis Libraries 


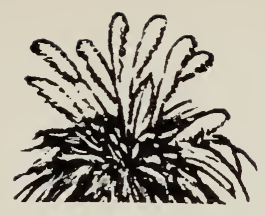

(69)

FOR CALIFORNIA'S MIDDLE ELEVATION DESERT 


\section{ORNAMENTALS FOR CALIFORNIA'S MIDDLE ELEVATION DESERT ${ }^{1}$}

\section{CALIFORNIA DESERTS}

Sections of three well-known deserts comprise nearly the entire eastern part of California. They lie east of a chain of high mountain ranges, extending from Oregon into Mexico, which form a generally effective barrier to eastward movement of moist Pacific air masses. These deserts all lie in California's PLANTCLIMATE V (figure 1) and include the driest, the hottest, and nearly the coldest sections of California.

In east-central and northeastern California lies the western edge of the Great Basin Desert. This is California's HIGH ELEVATION DESERT, with valleys 4500 to 6000 feet high and plateaus ranging from 6000 to 8000 feet. The climate ranges from arid, cold-temperate to subalpine in higher elevations. In east-central and southeastern California are large sections of the Mojave and the Colorado Desert portion of the vast Sonoran Desert complex. The latter is California's LOW ELEVATION DESERT; its climate is subtropical throughout. Its upper elevation (1000 feet above sea level) coincides with the approximate upper climate limit of subtropical conditions. It includes cultivated valleys from 120 to nearly 200 feet below sea level. Death Valley is located in the Middle Elevation Desert but is considered part of the Low Elevation Desert due to its elevation. California's MIDDLE ELEVATION DESERT is nearly half of the Mojave Desert. Its climate ranges from arid-warm-temperate to arid-cooltemperate in higher valleys, and to subalpine in high mountains.
In the Middle Elevation Desert, the authors' special attention was paid to fruit and nut growing, as the behavior of almond, apricot, peach, cherry, plum, pear, apple, pecan, walnut and olive trees provides unique information which can be related to behavior of ornamentals. Factors involved in such behavior are: winter temperature effectiveness in breaking dormancy; spring and fall frost conditions; summer temperature; location and boundaries of warm thermal zones or thermal belts (see "Glossary," pages 15-16) on air-drained slopes and low hills; and the effect of such things as varying exposures and mountain shelters.

The High Elevation Desert contains some 9,200 square miles, the Low Elevation Desert about 10,200, and the Middle Elevation Desert approimately 38,800 square miles. The total of all deserts, 58 ,200 square miles, is about 37 per cent of the state's area.

California's Middle Elevation and Low Elevation Deserts are closely associated geographically and climatically. These two deserts occupy an area about 380 miles long, northwest to southeast, and each desert extends almost the entire distance. East to west they are from 100 to 240 miles wide, narrowing to a point in the extreme north.

The Middle Elevation Desert has an area of about 38,800 square miles-approximately equal to the combined areas of Vermont, New Hampshire, Massachusetts, Rhode Island, Connecticut and Delaware plus one-third of Maryland.

\section{THE MIDDLE ELEVATION DESERT}

\section{Location and Elevation}

The Middle Elevation Desert (as here considered) includes all desert areas between 1000 and 7000 feet above sea level. In the north the boundary is the lower climatic limit of the High Elevation Desert, 7000 feet around Owens Valley to 5500 feet at the south end of the Inyo Mountains. Through central and southern California the western boundary gradually lowers from about 6000 feet on the east face of the Sierra Nevada at the south end of

${ }^{1}$ Submitted for publication April 28, 1967. 
Owens Valley, to below 4000 feet in southern San Diego County.

Main valley floors range from 2000 to 4500 feet elevation. The surrounding alluvial slopes rise to varying heights, differing with the size of the valley and with the elevation of the valley floor. These air-drained slopes extend as high as 6000 feet around the north end of Owens Valley. The Middle Elevation Desert includes arid-warm-temperate zone valleys and low mountains in southeastern San Bernardino County, and extends through Riverside into Imperial County to within a few miles of Mexico. It also includes the Owens Valley and smaller arid-cooltemperate zone valleys in Inyo County, where growing conditions and plant behavior are more like the Middle than the High Elevation Desert.

The Middle Elevation Desert has some mountain ranges or peaks higher than 7000 feet, and these result in several small "islands" exhibiting sub-alpine characteristics like those of the High Elevation Desert.

\section{Plant Selection and General Factors}

Choice of ornamental plants for each area must be determined by their suitability to the climate. Tolerance to low minimum and high maximum temperature is the most important single factor, but tolerance to dry atmosphere and wind is also important. Any one of the following factors importantly affects growth.

Water supply. Surface or gravity water for irrigation or domestic use is available only in the Palmdale Irrigation District, along the upper reaches of the Mojave River and in limited northern parts of the Owens Valley. In all other sections water for residential, agricultural or industrial uses must be pumped from underground basins. Water conditions are different in each of the more than 50 closed-basin drainage areas. Current water use exceeds annual recharge of the underground basins and is causing pumping levels to drop in many areas. With increases in population, and hence water use, this overdraft presents a serious problem. The California State Water Plan will bring water into and through the western extension of the Middle Elevation Desert, about 8 miles northeast of Gorman, and will supplement local supplies.

Water quality. Quality of water varies with origin. Water from deep underground basins is of excellent quality, as is gravity-source water. Water from shallow wells is sometimes saline enough to injure plants. Information in water quality in local areas may be available from water companies, present users, and official county and state water agencies. Water of unknown quality should be analyzed before use.

Soils. Soils vary with drainage basins, with coarser materials high on valley slopes, grading usually to silts and clays on the valley floors. Valley bottoms are often lakes after heavy rains, highly saline when dry. Most valley soils are composed of alternate layers of coarse and fine-textured materials; as a result large areas of caliche occur (see "Glossary"). This layered composition can interfere with water penetration and drainage when irrigation is introduced. Localized drainage or saline problems can develop as a result-these require the introduction of drainage and leaching procedures. Some soils are highly calcareous, and cause iron chlorosis in susceptible species.

Management. Good management is vital for ornamental plantings and irrigation is the most important item. The problem is when to irrigate, how much to apply, whether to use basins, a system of small ditches and furrows or, if water under pressure is available, sprinklers to keep roots of plants in moist soil during the entire year. Desert natives (see "Glossary") require special consideration. Other management operations may include mulching to reduce evaporation, fertilizing, pruning, staking, protection from frost, wind and blowing sand, and pest and disease control.

Much information about management practices can be obtained from local nurserymen and landscape organizations. Well-kept home and community plantings can be visited and studied-a successful owner is usually glad to share experience. There are few books on gardening with particular emphasis on desert 


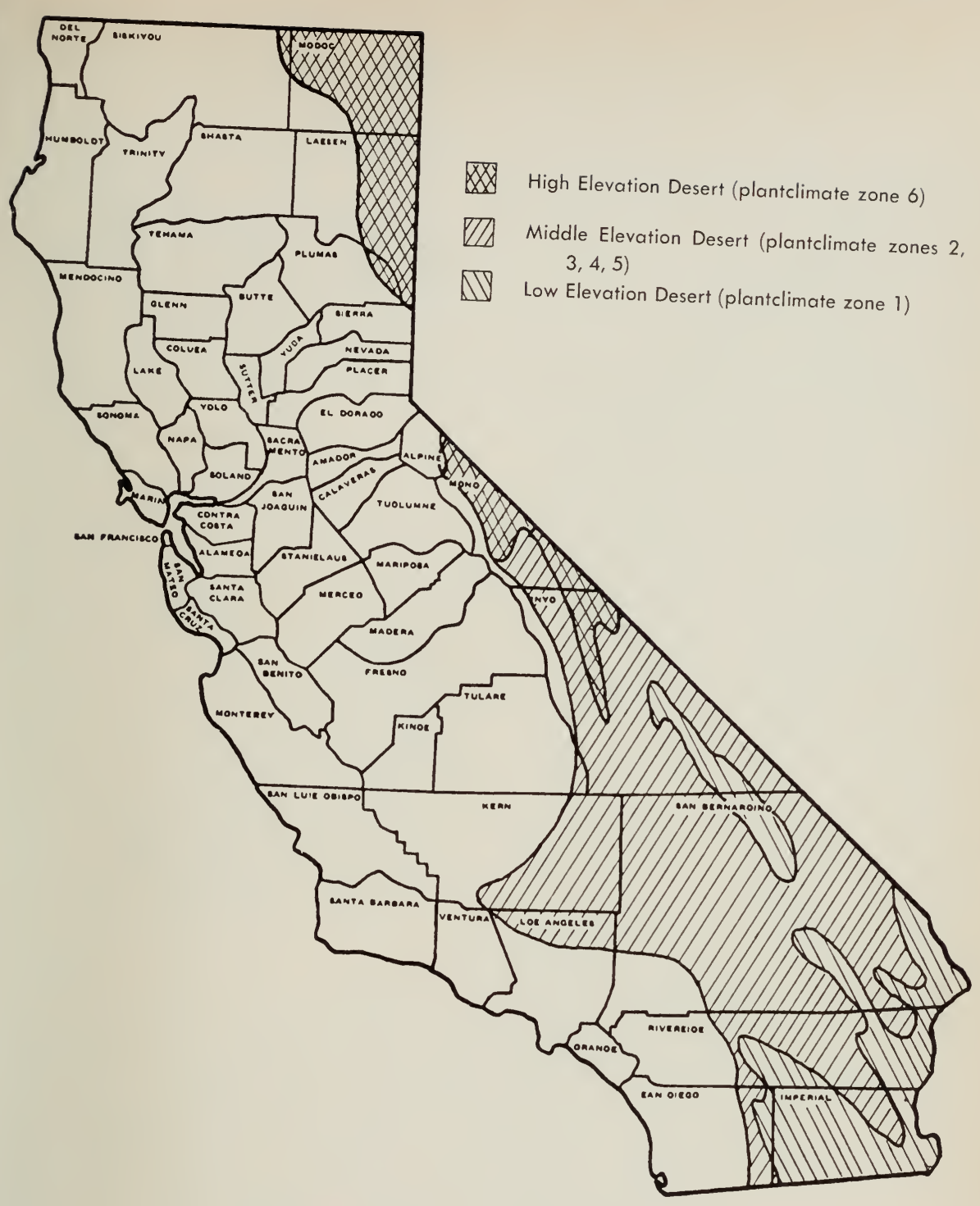

Fig. 1. Plantclimate V (includes plantclimate zones 1 to 6 ). 


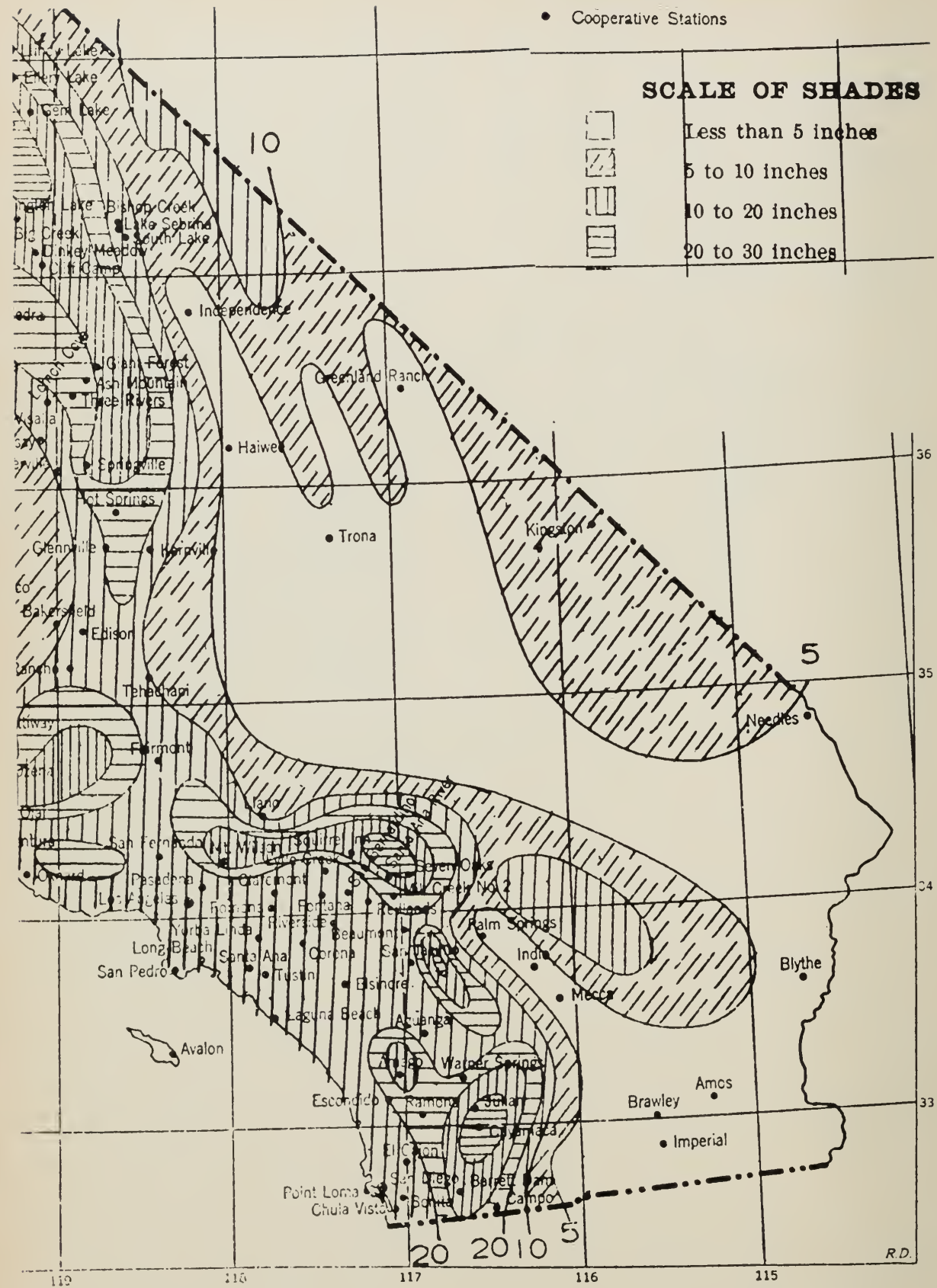

Fig. 2. Annual average rainfall, Middle and Low Elevation Deserts (courtesy of Environmental Science Services Administration, U. S. Weather Bureau). 
problems. The University of California's Agricultural Extension Public Service Office at 2200 University Avenue, Berkeley, 94720 , can supply lists of their publications in this field.

\section{General Climatic Conditions}

The temperature regimes for the Middle Elevation Desert are shown in graphic form on pages 11-13, and in tabular form on pages 18-23. Daily temperature fluctuations of 30 to 50 degrees or more are normal. Seasonal fluctuations are from 30 to 40 degrees.

Two kinds of cold. Two kinds of cold weather problems occur and are important considerations in plant selection. The first is the normal seasonal low temperature, ranging from 10 to 12 degrees below monthly mean minimums; plants must be able to tolerate these temperatures. The second type of cold is the "once in 50 year" freeze when temperatures drop 20 to 30 degrees below the average of monthly mean minimums. Permanent plantings such as windbreaks and shade trees should be coldhardy for these extremes, as they require years to replace. An average of the lowest recorded temperatures in major subzones will be found on pages 18-23.

Rainfall. In the Middle Elevation and Low Elevation Deserts over 60 per cent of the area receives less than 5 inches of annual rainfall, and only a narrow bclt along the west and southwest boundary receives more than 10 inches (see map, page 6). The normal rainy season is late November through March, with a somewhat longer season at high elevations. Summer rain is localized and may be of cloudburst proportions.

Sunshine. The percentage of sunshine is high, with nearly all the area having 250 to 275 clear days, 45 to 70 partly cloudy, and 40 to 50 cloudy days.

Humidity. The high number of days of sunshine, high temperatures and low rainfall results in exceedingly dry atmosphere. As a result, evaporation and plant transpiration are high. Humidity is high only during rainy periods. Humidity in the rainy season is between 30 and 60 per cent during daylight hours, but is as low as 5 to 20 per cent during the dry season. Growing season. Page 8 shows the number of days between the last spring and first fall day with a 32 degree minimum. Significantly longer growing seasons occur on air-drained slopes above all valleys, resulting in freedom from 32 degree frosts but more importantly from 28 degree frosts-particularly in spring, which allows fruit growing and successful use of more tender ornamentals. The difference between Palmdale, 2655 feet elevation with a 225 day growing season, and Palmdale Airport, 2517 feet and a 205 day growing season illustrates this point. The bloom of pears and other fruit usually escape spring frost near Palmdale, but are injured by frost too often for commercial orchard operations in the vicinity of the airport, which is about 2 miles out onto the valley floor. Still warmer conditions exist at higher elevations south and west of Palmdale, and there are similar contrasts on slopes above Bishop, Tehachapi, and other places within shorter distances. Growing seasons based on 28 degrees will be from 25 to 50 days longer than on these valley floors.

Wind. Most areas have a prevailing breeze of 10 to 20 miles per hour during the day. In a few sections winds of 40 to 70 miles per hour occur in every month of the year; these greatly restrict choice of ornamentals or commercial crops, although temperatures are not greatly modified. All sections have occasional severe wind storms, mostly in late fall to mid-spring and usually from a northerly direction. Summertime dust storms may also occur, and tornillos (see "Glossary") often cause severe localized damage. An 8 to 12 miles per hour afternoon breeze will increase the amount of water moving from leaves or moist soil into the air, resulting in faster use of soil moisture.

Wind is therefore a consideration in irrigation design and practice. Dry desert winds increase water loss from leaves and are a factor in drought tolerance.

Form and structure characteristics important in wind tolerance are well summarized in the following statement by 
GROWING SEASON, RAINFALL, AND ALTITUDE AT VARIOUS

\section{U. S. WEATHER BUREAU STATIONS IN MIDDLE ELEVATION DESERT*}

$\begin{array}{cccc}\text { Station } & \begin{array}{c}\text { Growing } \\ \text { season } \\ \text { (days) }\end{array} & \begin{array}{c}\text { Annual } \\ \text { average } \\ \text { rainfall } \\ \text { (inches) }\end{array} & \begin{array}{c}\text { Elevation } \\ \text { (feet) }\end{array} \\ \text { rears of } \\ \text { record }\end{array}$

Plantclimate zone 2, subzones 2.0, 2.1

(Arid-cool subtropical, and warm temperate slopes and valleys)

$\begin{array}{llllll}\text { Daggett Airport } & (2.0) & 255 & 3.58 & 1922 & 17 \\ \text { Hayfield Reservoir } & (2.0) & 275 & 3.95 & 1370 & 25 \\ \text { Trona } & (2.1) & 250 & 4.01 & 1695 & 30 \\ \text { Twentynine Palms } & (2.0) & 259 & 4.09 & 1975 & 25\end{array}$

Plantclimate zone 3 , subzones $3.0,3.0 \mathrm{w}, 3.1,3.1 \mathrm{w}$ (arid-moderate to cool temperate air-drained slopes, foothills, and low mountains $\dagger$

$\begin{array}{lllrrr}\text { Backus Ranch } & (3.1 \mathrm{w}) & 212 & 6.56 & 2645 & 24 \\ \text { Barstow } & (3.1) & 235 & 4.44 & 2142 & 20 \\ \text { Cantil } & (3.1 \mathrm{w}) & 230 & 3.90 & 2010 & 5 \\ \text { China Lake } & (3.1 \mathrm{w}) \ddagger & 204 & 2.30 & 2220 & 15 \\ \text { Fairmont } & (3.1) & 253 & 15.00 & 3060 & 30 \\ \text { Haiwee } & (3.1) & 234 & 5.94 & 3810 & 30 \\ \text { Inyokern } & (3.1 \mathrm{w}) & 218 & 3.85 & 2440 & 11 \\ \text { Llano Shawnee } & (3.1) & 207 & 6.99 & 3820 & 15 \\ \text { Palmdale } & (3.1) & 225 & 8.70 & 2655 & 28 \\ \text { Pahrump Valley } & (3.1) & 223 & 3.16 & 2830 & 3 \\ \text { Randsburg } & (3.0) & 244 & 5.85 & 3570 & 21\end{array}$

Plantclimate zone 4, subzones 4.0, 4.1, 4.2, 4.3, 4.3w (arid-cool temperate main valleys and cold-air basins)

$\begin{array}{lllllr}\text { Lancaster } & (4.3) & 213 & 4.90 & 2350 & 15 \\ \text { Llano } & (4.3) & 208 & 9.42 & 3490 & 14 \\ \text { Lucerne Valley } & (4.2) & 192 & 4.00 & 3015 & 8 \\ \text { Palmdale Airport } & (4.3) & 205 & 5.42 & 2517 & 17 \\ \text { Victorville } & (4.3) & 193 & 5.41 & 2859 & 22\end{array}$

Plantclimate zone 3 , subzones $3.2,3.2 w, 3.3,3.3 w$ (arid-moderate to cool temperate, air-drained slopes, foothills, and low mountains)

$\begin{array}{llllll}\text { Independence } & (3.2) & 207 & 4.99 & 3950 & 16 \\ \text { Yucca Grove } & (3.2) & 201 & 7.01 & 3951 & 18\end{array}$

Plantclimate zone 4, subzones $4.4,4.5,4.6$ (arid-cool temperate high elevation valleys)

$\begin{array}{lllrrr}\text { Bishop Airport } & (4.5) & 150 & 5.50 & 4108 & 40 \\ \text { Tehachapi } & (4.4) & 163 & 10.66 & 3975 & 20\end{array}$

* No data available for plantclimate zone 5. See page 9 for explanation of subzones.

$\uparrow$ Valyermo omitted because station is located in cold, narrow canyon. Areas of persistent crop-influencing winds have the letter "w" after their subzone designation.

+ Data from U. S. Naval Air Station. 
Eric Johnson (personal communication):

"Certain forms and structures are common in trees and shrubs that have tolerance for wind. Trees will have a strong single trunk with thick tough bark to withstand the cutting of blowing sand. Branching will be wideangled rather than with narrow " $V$ " crotches which tend to split. Trees will have the ability to "grow into the wind," thus forming a uniform top without a "lean." Wood will be tough, supple and yielding so it will bend and not break. Plants with brittle wood should be avoided. Small relatively thick, wax-coated leaves, or leaves that are needle-like will offer less wind resistance and hence cause less strain on branches and trunk, and are less likely to be torn and shredded. Root systems should penetrate deep into the soil for a solid foundation and anchor and be wide-spread for water absorption. In shrubs the same factors apply. Many shrubs will be found with gray, hairy leaves, a good indication of drought and wind tolerance."

Wind and drought tolerances of various plants will be found in the plant list (starting on page 24).

Windbreaks. Carefully planned and managed windbreaks add to living comfort and to diversity of plantings, and they can almost eliminate detrimental effects of winds. A good example of an effective windbreak is the planting on the Los Angeles Bureau of Water and Power headquarters north of Mojave: ornamentals that would not survive outside are growing within the sheltered area with little or no indication of injury. However, the microclimate (see "Glossary") within sheltered areas may result in a pool of relatively still air 2 to 4 degrees warmer in daytime or colder at night. This can be particularly important during blooming season; daytime warmth can advance bloom and pooled nighttime coolness can increase frost hazard enough to necessitate appropriate frost protection.

Windbreaks may require plantings on two or three sides but rarely on four. Because they are permanent, kinds and varieties should be selected not only for tolerance of and resistance to wind, but also for ability to withstand occasional temperature extremes. Windbreaks should be moderately wind-permeable near the ground to avoid the pooling of air; tops should be dense and solid to give equal protection during summer or winter. For single-row plantings where space is limited, closely planted, erect growing evergreens will be most satisfactory. Arizona Cypress, Cupressus glabra, planted 4 to 6 feet apart is a good example. Mixed conifers, evergreen, and deciduous trees and shrubs can be selected to serve as a windbreak and source of summer shade.

\section{PLANTCLIMATE ZONES AND SUBZONES}

In more developed areas of California, plantclimate zone and subzone boundaries were located as a result of long experience with a wide range of cultivated plants. A subsequent study of temperature data in the subzones revealed only slightly differing temperatures at official Weather Bureau stations many miles apart but having nearly the same elevation and exposure. In the desert, a study of temperature data for widely separated areas having nearly the same elevation also revealed a comparable temperature similarity. Therefore, in large sections of the desert where development is limited and widely scattered it is necessary to rely on elevation extensions on contour levels to establish the subzone. The authors are confident the resulting subzone boundaries will be ciose to the actual. Many of the subzone boundaries of the Low Elevation and Middle Elevation Deserts (see folded map, inside back cover) have been established by this method. It must be recognized, however, that within subzones of relatively uniform conditions, there are variations in slope and exposure within short distances which are responsible for conditions normally 
experienced in subzones some distance away.

In Plantclimate $\mathrm{V}$, differences in adaptation and behavior of various plant species result in delineation of six progressively cooler plantclimate zones, and these are numbered 1 to 6 . Each such zone includes progressively cooler subzones: $1.0,1.1,1.2$, etc.

Desert plantclimate zones:

1-Low Elevation Desert plantclimate zone, with 10 plantclimate subzones
2, 3, 4, 5-Middle Elevation Desert plantclimate zones, each with two to seven plantclimate subzones

6-High Elevation Desert plantclimate zone, with several plantclimate subzones.

Because Low Elevation and Middle Elevation deserts are so closely associated geographically, and because the division established for this publication is based on plantclimate relations, a brief description of the Low Elevation Desert is included.

\section{LOW ELEVATION DESERT}

\section{Plantclimate Zone 1}

Under 1000 feet elevation with subtropical temperatures. Normal winter frosts to 26 or 28 degrees with occasional freezes to 15 or 18 degrees (12-15+ year interval). Growing season 300 days or more. Typical crops: winter lettuce, very early tender vegetables such as summer squash, zucchini, etc. Citrus (principally grapefruit) is adapted to nearly all except lowest, coldest spots. Bermudagrass is the dominant lawn grass.

\section{MIDDLE ELEVATION DESERT}

\section{Plantclimate Zone 2. Arid-cool subtropical, warm-temperate slopes and valleys}

This is a transition area between subtropical Low Elevation Desert and typical temperate zone conditions of the main valleys of the Middle Elevation Desert. Elevation is 1000 to 2200 feet. Normal winter minimums are as low as 20 to 22 degrees; occasional extremes range from 10 to 14 degrees; growing season is 250 to 280 days. The upper boundary is the climatic limit for the rice-bermudagrass plant association, hence bermudagrass is the dominant lawn grass. Subtropicals such as citrus (Citrus sp.), bougainvillea (Bougainvillea sp.), evergreen pear (Pyrus kawakamii), southern live oak (Quercus virginiana), and jujube (Zizyphus jujaba) are successful only in warm sheltered south to southwest slopes and are not found much above the 1000 foot level; deciduous fruit with low-chilling requirement such as apricots, almonds, some peaches are grown; blossom injury due to spring frost has been observed on lowchilling varieties in years of early bloom; and summer heat will cause some loss of fruit quality. In warm sections, common lilac will show some delayed foliation and relatively poor bloom. There are two subdivisions of this plantclimate, 2.0 to 2.1 . Subzone 2.0 is under 2000 feet and includes cool subtropical areas. Subzone 2.1 is Hinkley Valley at 2200 feet, Searles (Trona) and Panamint (northeast of Trona) Valleys, a border around Death Valley, and small valleys in southern Inyo County below 2000 feet elevation.

\section{Plantclimate Zone 3. Arid- moderate to cool temperate air-drained slopes, foothills and low mountains}

This plantclimate zone could be termed "Desert Deciduous Fruit Plantclimate Zone" because it consists of air-drained thermal zones above cold valley floors. The longer growing season permits bloom and young fruit to escape spring frost. 


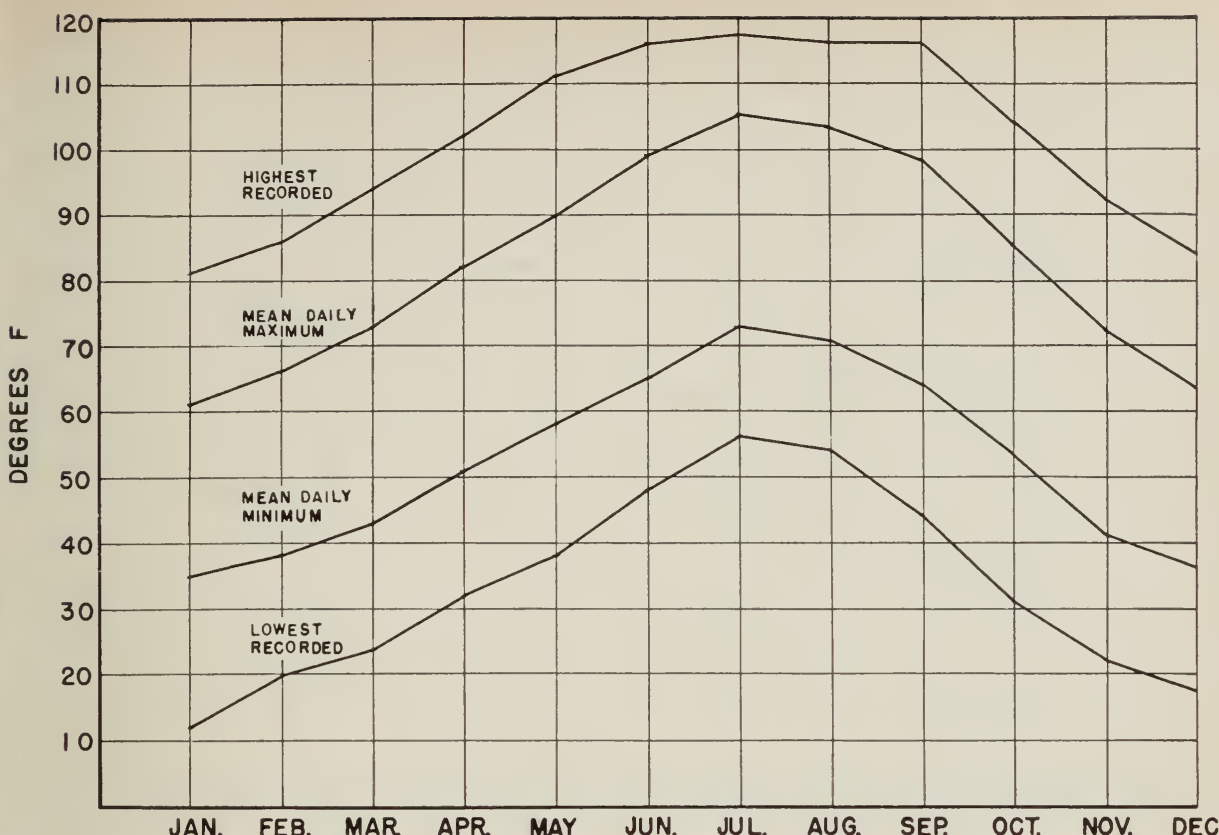

Fig. 3. Average temperature: cool-subtropical, warm-temperature slopes and valleys of zone 2, subzones $\mathbf{2 . 0}$ and $\mathbf{2 . 1}$, shown on map on inside back cover.

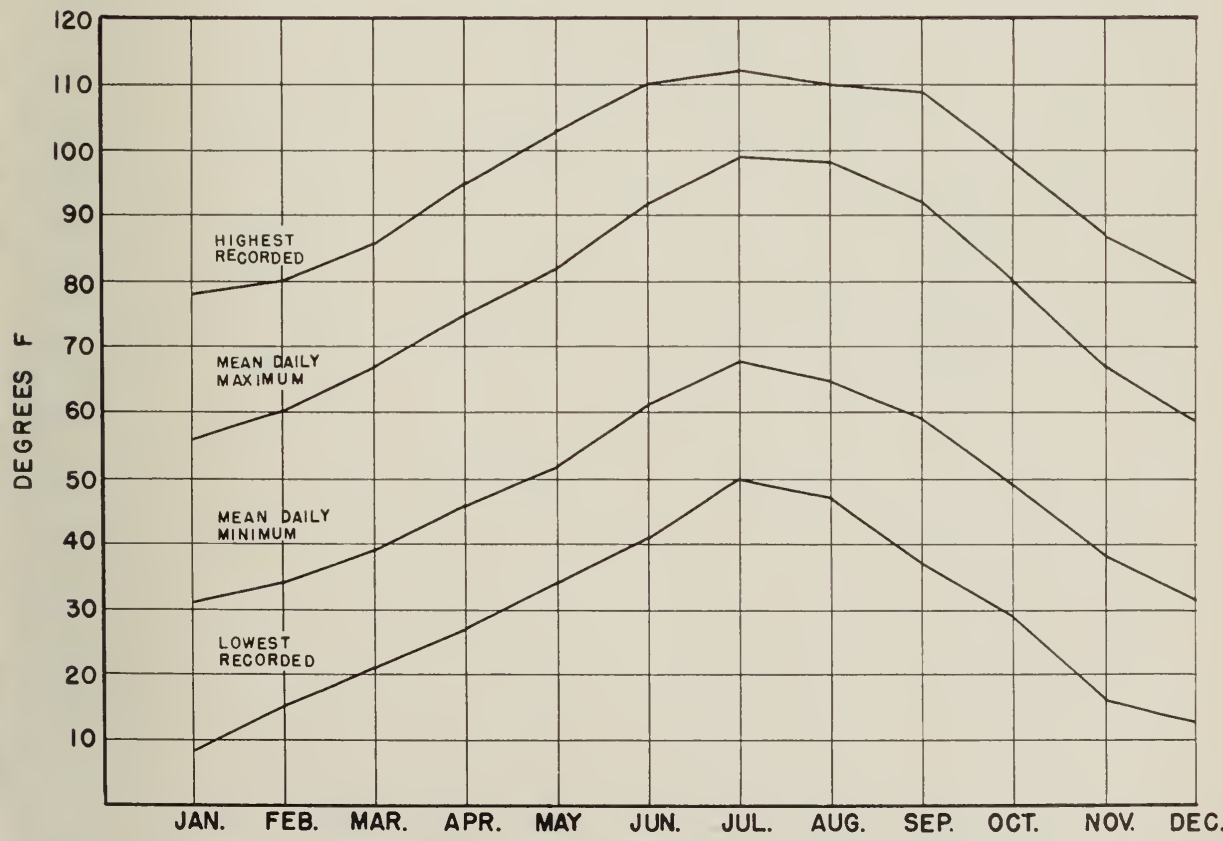

Fig. 4. Average temperature: moderate to cool temperate air-drained slopes, foothills, and low mountains of zone 3, subzones 3.0, 3.0 w, 3.1, and 3.1 w, shown on map on inside back cover (the letter " $w$ " indicates that the subzone has persistent crop-influencing winds). 


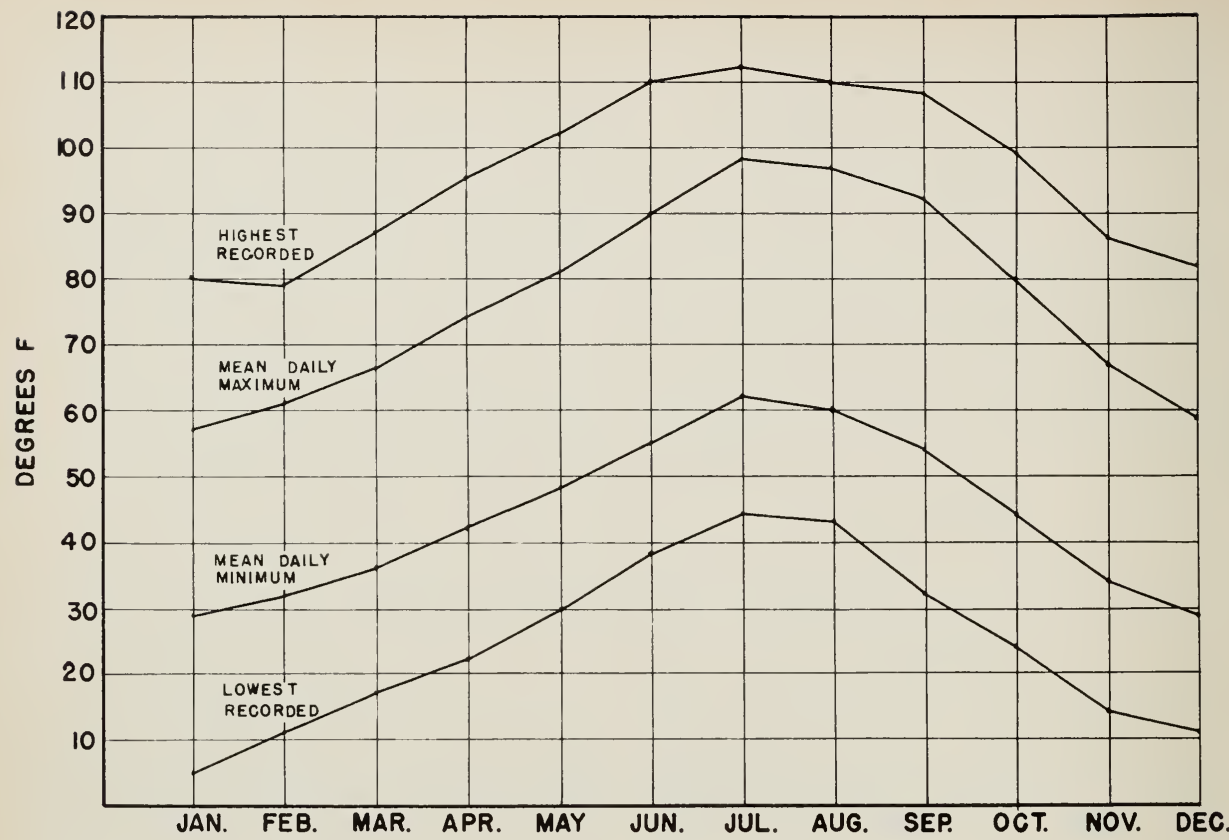

Fig. 5. Average temperature: cool temperate main valleys and cold-air basins of zone 4, subzones 4.0, 4.1, 4.2, 4.3, and 4.3 $w$, shown in map on inside back cover.

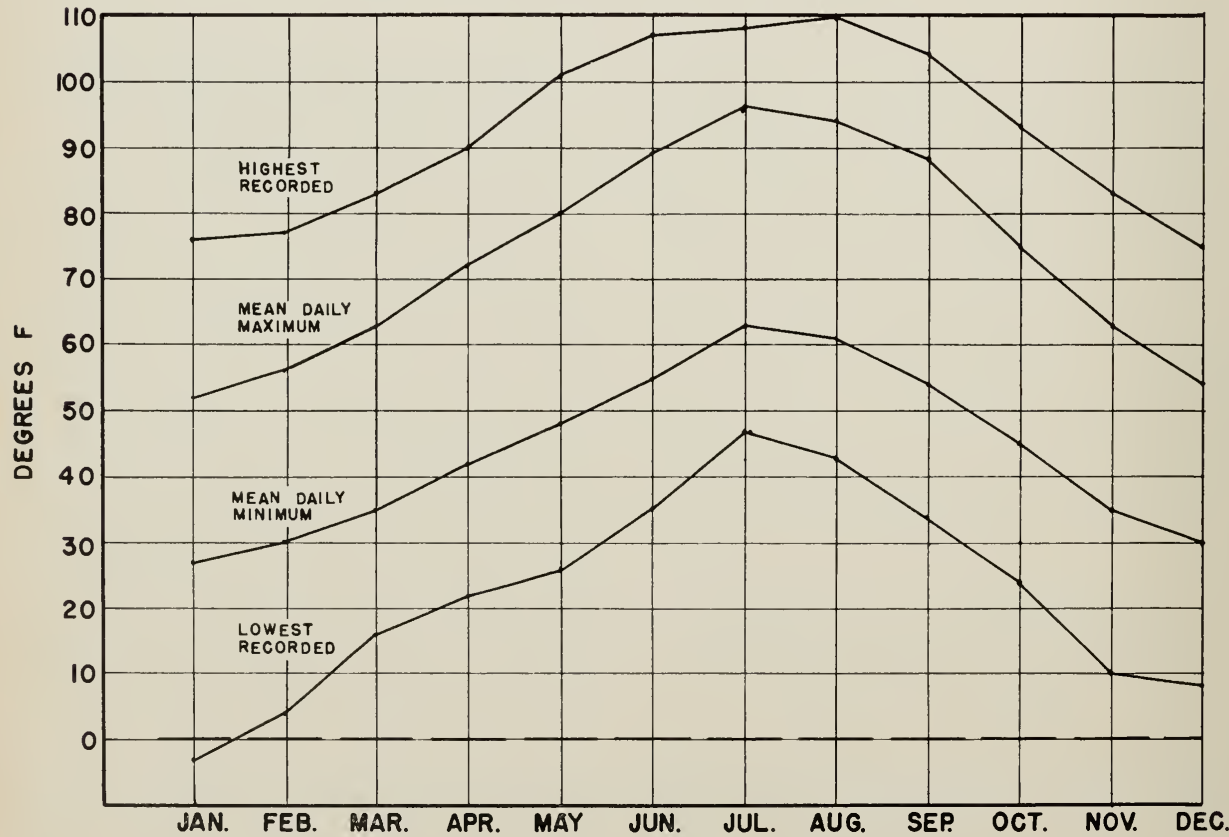

Fig. 6. Average temperature: moderate to cool temperate air-drained slopes, foothills, and low mountains of zone 3 , subzones 3.2, 3.2w, 3.3, and 3.3w, shown in map on inside back cover. 


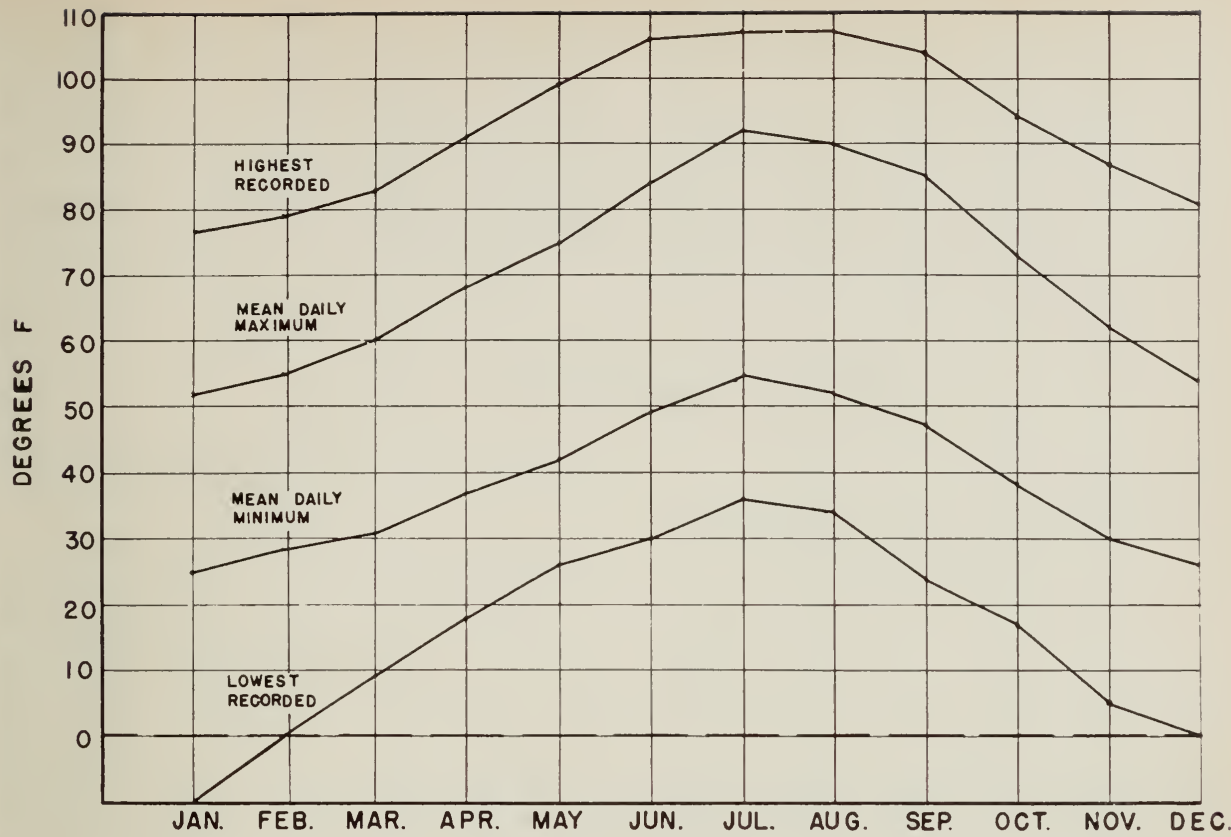

Fig. 7. Average temperature: cool temperate high elevation valleys of zone $\mathbf{4}$, subzones 4.4, 4.5 and 4.6, shown in map on inside back cover.

Similarly, the entire plantclimate zone is suitable for the common Eastern lilac, peonies, and other ornamentals requiring winter chilling. French hybrid lilacs may be somewhat delayed in warmer sections of subzone 3.0. Bluegrass is the dominant lawn grass. Annual flowering plants should not be planted until after spring frost unless protection can be supplied. A wide choice of suitable temperate zone ornamentals is shown in the plant list (page 24).

Four subzones are divided into two groups: 3.0 and 3.1 adjacent to the main valleys, and 3.2 and 3.3 adjacent to highelevation valleys.

Slopes adjacent to main valleys. Subzone 3.0 ranges from 2000 to 4500 feet elevation. In this subzone it is found that the growing conditions are cooler than those of plantclimate zone 2 due to elevation, but warmer than subzone 3.1 because of cold air drainage. This latter is illustrated by the location of Randsburg, elevation 3520, in subzone 3.0. Records show 244-day growing season compared to 204 to 235 days, and a monthly mean minimum temperature from 1 to 4 degrees above the average for all stations in the 3.0 and 3.1 grouping that includes Randsburg. In subzone 3.0, where wind is not a physical deterrent, almonds, apricots, grapes, sweet cherries, and medium chilling requiring peaches and pears will be satisfactory-this indicates that common lilac, Bleeding Heart, Peony, and similar medium-chilling-requiring ornamentals will be satisfactory.

Subzone 3.1 occupies thermal slopes above main valley floors of plantclimate subzone 2.1 in southern and eastern Inyo County, with the major portion above plantclimate subzones 4.1 and 4.3 in Los Angeles and Kern counties. Elevations range from about 2700 to 4700 feet. The growing season is from 204 to 235 days, except for Fairmont where the U. S. Weather Bureau station is near a ${ }_{1 / 4}^{1 /}$-square mile reservoir which modifies local temperatures. The full range of winter-coldrequiring ornamentals will perform satisfactorily. 
Slopes adjacent to high valleys. Elevation of subzone 3.2 ranges from 3000 or 3200 feet at the south end of Owens Valley to 5000 or 5500 feet above Independence. Spring frosts are too frequent for almonds, apricots, and early blooming peaches, but high-winter-chilling varieties of peaches, pears, and apples will usually be satisfactory in the garden. Subzone 3.3 will be too cold for reliable peach and pear production. All ornamentals and garden fruits valued for their spring bloom are somewhat unpredictable.

\section{Plantclimate Zone 4. Arid-cool temperate valleys and cold-air basins}

Seven subzones, 4.0 through 4.6 , are required to delineate variations found in main valley floors and cold-air basins. The subzones have been divided into two groups-main valleys and high valleys.

Main valleys and cold-air basins. Subzones 4.0, 4.1, 4.1w, 4.2, 4.3 and $4.3 \mathrm{w}$ range in elevation from 2300 to 3500 feet. Growing season varies from 192 to 213 days. Crops of the main valleys, hence choice of ornamentals, are limited by late spring frosts which will damage bloom in many years. Normal winter minimums range from 15 to 20 degrees, with occasionally 0 to 10 degrees. Bluegrass will be the dominant lawn grass but Bermudagrass will survive.

These subzones are the upper limit for Forbes cypress (Cupressus forbessi), several junipers (Juniperus sp.) and pines (Pinus sp.), California live oak (Quercus agrifolia), desert willow (Chilopsis linearis), oriental sweet gum (Liquidambar orientalis), Chinese elm (Ulmus parvifolia), pampas grass (Cortaderia selloana), ice plant (Mesembryanthemum sp.), lippia (Phyla nodiflora), European grape (Vitis vinifera), and oleander (Nerium oleander). High elevation valleys and cold-air basins. This section of plantclimate zone 4 , namely 4.4, 4.5 and 4.6, ranges in elevation from 3200 to 5000 feet. Growing season varies from 150 to 165 days. Normal winter minimum temperatures range from 7 to 15 degrees with occasionally -3 to 5 degrees. Annual flowers should be planted late or given ample protection.

\section{Plantclimate Zone 5. Mountains}

This includes all areas above the estimated upper level of deciduous fruits, and varies from 4500 feet in the south to 6200 feet in the north, with some mountains over 10,000 feet. Mountains are all cool temperate, cold temperate, or sub-alpine at the highest peaks. Mountain areas are non-agricultural except for grazing. Summer rains produce fair pasture grass in some areas between 4500 and 8000 feet elevation. Ornamental plantings will be subject to frosts any month, and species should be selected for cold hardiness. There is a surprising number of conifers, deciduous trees and shrubs, vines, and ground-covers suitable to mountain climates. A few examples are giant sequoia (Sequoiadendron giganteum), Japanese flowering quince (Chaenomeles japonica), spiarea (Spiraea sp.), some lilacs (Syringa sp.), Boston ivy (Parthenocissus tribuspidata), concord grapes (Vitis labrusca), strawberry (Fragaris sp.), and peony (Paeonia sp.).

\section{PLANT LISTS}

Palms, coniferous trees and shrubs, broadleafed evergreen trees and shrubs, deciduous trees and shrubs, vines and ground covers are listed by groups (starting page 24). No attempt has been made to catalog the large number of herbaceous perennials such as Bleeding Heart, Daffodil, Tulip, etc., or the annual flowering plants. A wide choice of the latter is available for planting in the many miniclimates (see
"Glossary") of a windbreak shelter. Success depends on understanding their management requirements.

Plants listed were actually observed by the authors, and most had been growing satisfactorily in the Middle Elevation Desert for 5 years or more. They are scored in three grades of drought tolerance: drought tolerant to a high degree, as with desert natives; moderately drought 
tolerant plants that will use large quantities of water if available, but which will do reasonably well on greatly reduced supplies-olive, oleander, some palms, almond; not drought tolerant requiring regular irrigation and plenty of water, such as roses, elms, willows, myrtles, privets or spiraea.
While the many plants listed provide considerable choice in landscape effect, some owners will want to try others. Experienced nurserymen in desert areas will be found to have many new kinds available-your nurseryman is well aware of the need to choose and introduce plants suitable for such areas.

\section{GLOSSARY}

CALICHE-A soil having rock-like layers, from a few to many inches thick, of sand and gravel cemented together by calcium carbonate. There are extensive areas of this in deserts, usually a few inches to several feet below the surface. Water may penetrate very slowly, hence the soil above is liable to become saline. Lavers will not re-cement if broken. Iron chlorosis is characteristic, even after break-up and the establishment of drainage.

CHILLING REQUIREMENT-Most deciduous trees and shrubs (those which are leafless during the winter) and some other temperate zone plants, such as tulips and daffodils, require varying amounts of cold temperature during their dormancy to condition them for normal spring growth. Severe lack of winter chilling will result in lack of fruit set and exceedingly delayed spring development-a condition known as "delayed foliation" or "dormosis." Almonds, apricots, and few peach varieties need but relatively short periods below $45^{\circ} \mathrm{F}$ and are said to have a low chilling requirement. Under these conditions lilacs, daffodils, tulips, Japanese flowering quince, and similar plants may not bloom satisfactorily. Most varieties of peaches, pears, cherries, plums, nectarines, some early apples and Placentia and Ehrhardt walnuts can be considered as having a medium or moderate chilling requirement. Under these conditions, lilacs, daffodils, and tulips will be satisfactory. Late apples, peaches, pears, and Eureka and Franquette walnuts have a high chilling requirement.

CULTIVARS-Plant variant, or variety, resulting from induced or natural mutations, hybridization, etc. and maintained only by cultural operations, such as selection, vegetative propagation, roguing, and isolation.

DESERT NATIVE-Indigenous or naturally introduced plants that live and thrive in various parts of the Middle Elevation desert. They are all significant for their ability to survive on limited, and mostly wintertime, water. Most of them are intolerant of heavy summer watering common to garden irrigation. The desert natives should be planted together and managed as a unit with very limited summer irrigation. All will benefit from deep watering in winter.

GROWING SEASON-The frost-free period between spring and fall minimum temperatures of 32 degrees.

IRON CHLOROSIS-Yellowing of leaf tissue between veins, most noticeable on new growth. In severe cases leaves become almost white, will sunburn and drop. Caused by high lime content of soil preventing the absorption of iron by the plant. Specially prepared iron can be applied to the soil or used as spray to correct the trouble.

LAWN WATERING_-With a sprinkler system a lawn is usually watered frequently and with amounts that will penetrate the soil below the grass roots, thus keeping the soils below 6 to 8 inches continually wet. On the other extreme, with hand sprinkling the deeper soils almost always become dry. Both conditions, continually wet or extremely dry, are unfavorable for many trees and shrubs with deep root systems. Differential irrigation between shallow-rooted grasses and deeper-rooted trees and 
shrubs is essential. This calls for frequent light irrigations of the lawn. Deep soaking 1 to 2 or 3 months apart, depending upon soil and season, will prevent over-irrigation of the deep rooted plants.

PLANTCLIMATE-A definable physical climate distinguishable from others by kinds of plants and their performance, or conversely plant kinds and performance that can be predicted and described from knowledge of the physical climate. There are five PLANTCLIMATES which are statewide or larger. Each plantclimate has optimum seasonal conditions for specific plant groupings or associations. These same groupings or associations may be found in other plantclimates, but performance is inhibited to varying degrees because of differences in the physical climate. Each major plantclimate is divided into several REGIONAL PLANTCLIMATES within which the groups or associations of plants and their performance are increasingly specific. The same regional plantclimates may exist in more than one major plantclimate. Regional plantclimates are composed of PLANTCLIMATE ZONES. A plantclimate zone is a geographical area in which certain rather broad groups of plants having specific climatic (principally temperature) requirements will grow satisfactorily, soil and water assumed favorable. A PLANTCLIMATE SUBZONE is part of a plantclimate zone in which only a few kinds and varieties of the general plant group and the physical climate are in complete harmony resulting in consistent performance. Within the subzones there are MICRO-plantclimate subzones (or micro-subzones) - small portions of the larger areas that because of exposure or shelter (either natural or man-made) cause a slightly different plant reaction. The differences can be as great as the difference between adjoining subzones, but usually will be less. Micro-subzones vary from a few square miles or less to the area enclosed by an effective windbreak around a homesite. Within these micro-areas are many MINI-plantclimate subzones (mini-subzones). These are small areas of a few square feet, perhaps on the south face of a wall between large sheltering shrubs where reflected heat will accumulate, under an evergreen tree for shade effect, etc.

TEMPERATURE-All temperatures are in degrees Fahrenheit, and data are from U. S. Weather Bureau published records.

THERMAL ZONE, OR THERMAL-In this publication the term is used to indicate a warm zone or belt on hillsides, slopes, and moderate elevations, from which cold air drains to the lower lying valley floor or cold air basin. Thermal zones are often 5,10 or 15 degrees warmer than their adjacent low areas. This difference is particularly apparent during spring and fall frost periods.

TORNILLO-A small but violent "dust devil," or whirlwind.

VARIETY -A plant variant found in the wild.

\section{COMMUNITIES VISITED DURING PLANT SURVEY OF MIDDLE ELEVATION DESERT}

\section{Community}

Adelanto

Apple Valley

Antelope Valley Field Station

Backus Ranch (6 miles

Baker

\section{Plantclimate subzone}

4.1

4.0

4.3

northwest of Rosamond)*

\section{Community}

Barstow *

Big Pine

Bishop Airport*

Boron

Barnhart Nursery (near Yucca)
Plantclimate subzone

3.1

3.3

4.5

$4.3 \mathrm{w}$

2.0 


\section{Community}

Cantil ${ }^{*}$

Chandler's (Holland Summit)

China Lakef

Cool Water Ranch (near

Daggett)

\section{Daggett Airport ${ }^{*}$ \\ Daggett Marine Base}

Edwards Air Force Base

Fairmont $^{*}$

Frazier Park

Fort Tejon

Freeman Gulch

Gorman

George Air Force Base (near Victorville)

Haiwee *

Hayfield Reservoir *

Hesperia

Helendale

Hinkley

Holland Summit

Homestead (Indian Wells)

Hutchinson Nursery (near Barstow)

Independence

Indian Wells (Homestead)

Inyokern *

Jess Ranch (near Apple Valley)

Joshua Tree

Lancaster *

Lebec

Leona Valley

Littlerock

Llano*

Llano Shawnee

Lucerne Valley*

Lone Pine

Ludlow

Mojave

Monolith
Plantclimate

subzone

$3.1 \mathrm{w}$

3.1

$3.1 \mathrm{w}$

2.0

2.0

$4.3 w$

3.1

3.1

3.1

$3.1 \mathrm{w}$

3.1

4.3

3.1

2.0

3.0

3.0

2.1

3.1

$3.1 \mathrm{w}$

3.1

3.2

$3.1 \mathrm{w}$

$3.1 \mathrm{w}$

4.0

4.0

4.3

3.1

4.0

3.1

4.3

3.1

4.2

3.2

2.0

4.3

3.2

\section{Community}

Morongo Valley

Mt. Whitney Fish Hatchery

Mountain Pass

Neenach

Newberry

Olancha

Onyx

3.0

Oro Grande

4.3

3.1

3.1

4.3

3.1

3.1

3.0

Phelan

3.1

Quail Lake

Quartz Hill

3.1

3.0

$3.1 \mathrm{w}$

4.3

Ridgecrest

Sandberg (old Forestry Station)

3.1

Shoshone

Simi Corners

2.1

4.3

Tehachapi (town) ${ }^{*} \quad 4.4$

Tehachapi (surrounding) $\quad 3.3$

Three Points

3.1

Trona $^{*}$

Twentynine Palms

2.1

2.0

Valyermo

Van Dyke Ranch (near Daggett)

Victorville*

Vincent Fire Station

3.1

2.0

4.3

3.1

White Water

Willow Springs

$2.0 \mathrm{w}$

3.1

Yermo

2.0

Yucca

Yucca Grove*

2.0

3.2

Yucca Valley

"Location of U. S. Weather Bureau cooperative stations; "w" indicates crop-influencing winds.

† Data from U. S. Naval Air Station. 


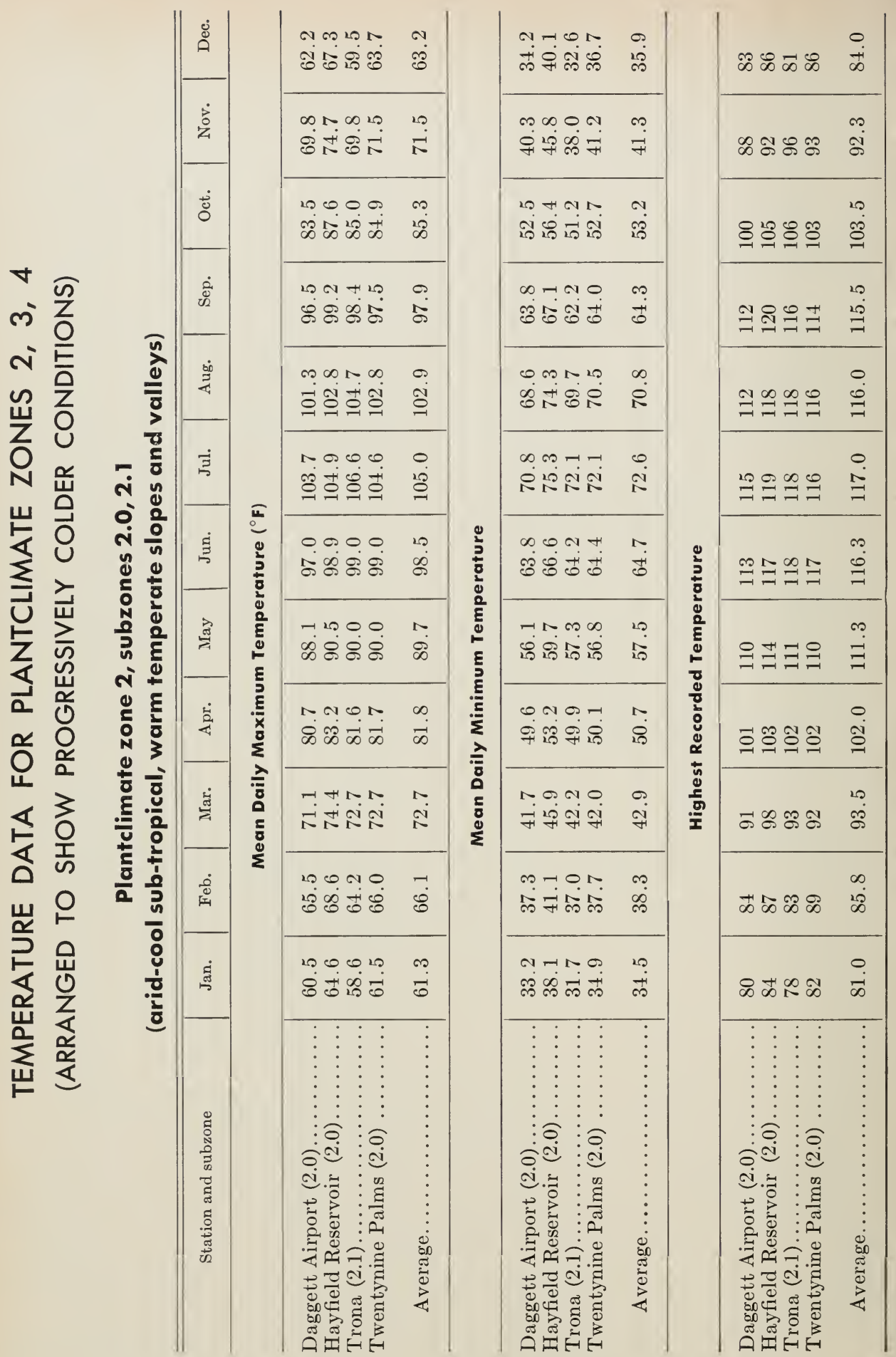




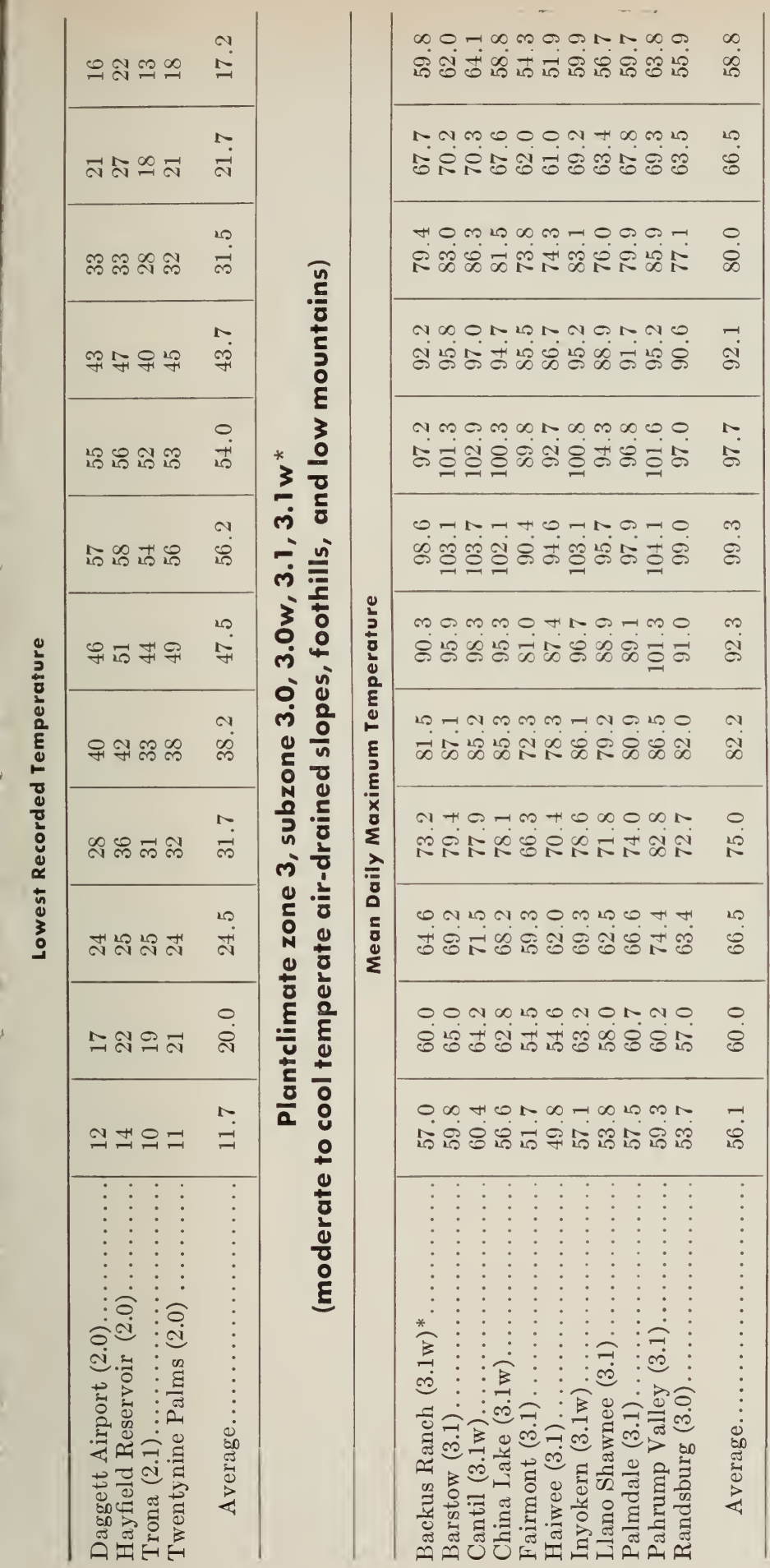

o o arnol

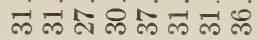

ONNHNON-

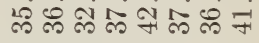

NOONONNH

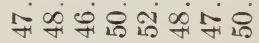

He h n $20 \pi \infty$ เ

0 H

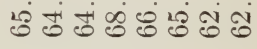

con 0000 ธலธல

$n$ ansmeno

ช 8 ชิ

tam a o $0-n$

ถิ่ ถู่ ถิ่

An hmolat

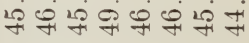

$0.5 n=0,000$

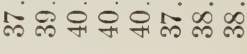

mol $0000 \mathrm{nt}$

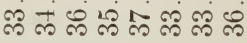

$0 \ln \infty-\infty \circ \mathrm{N}$

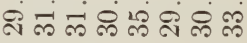

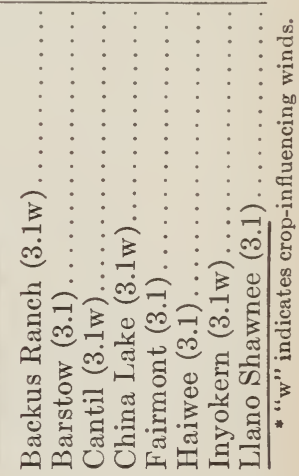




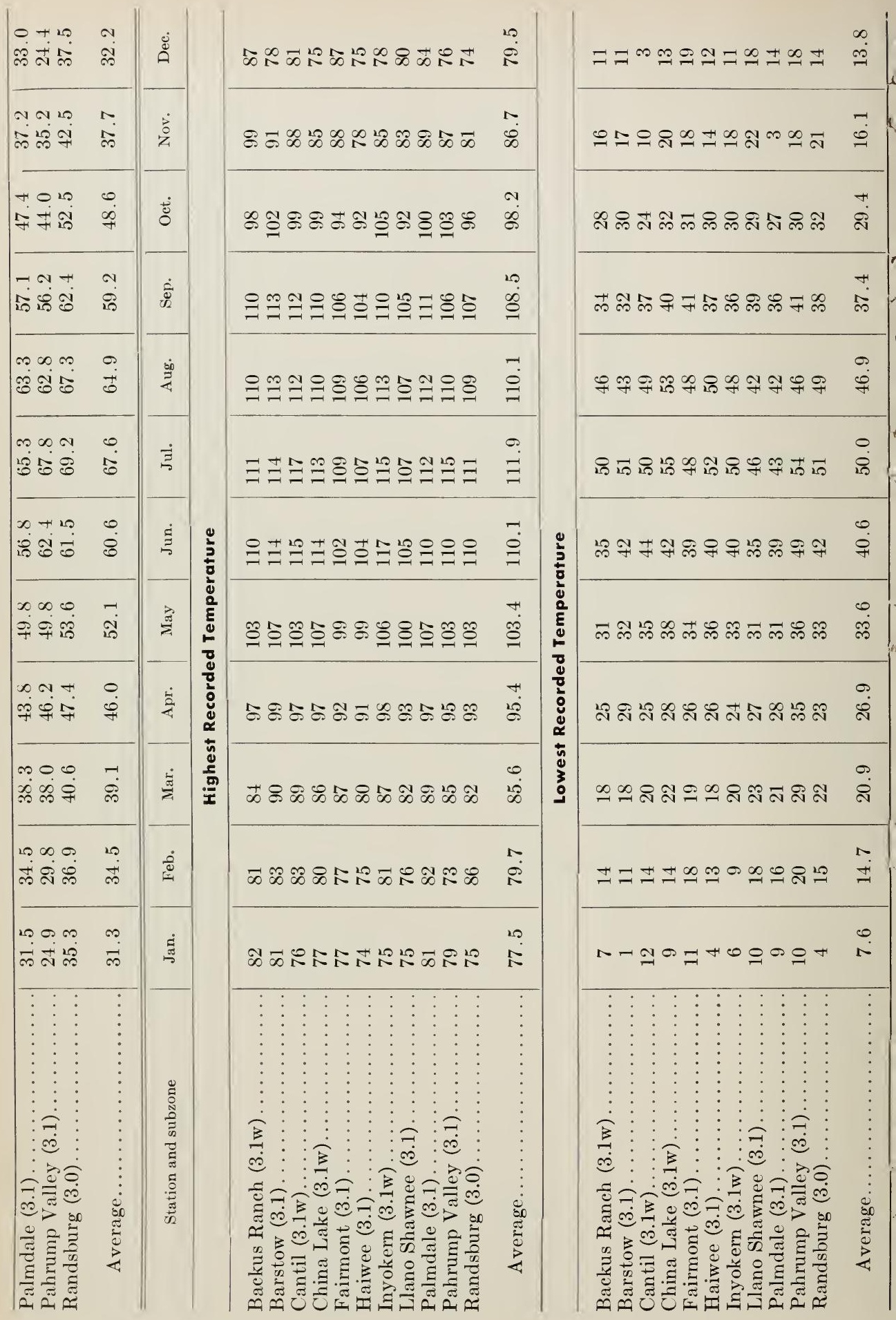




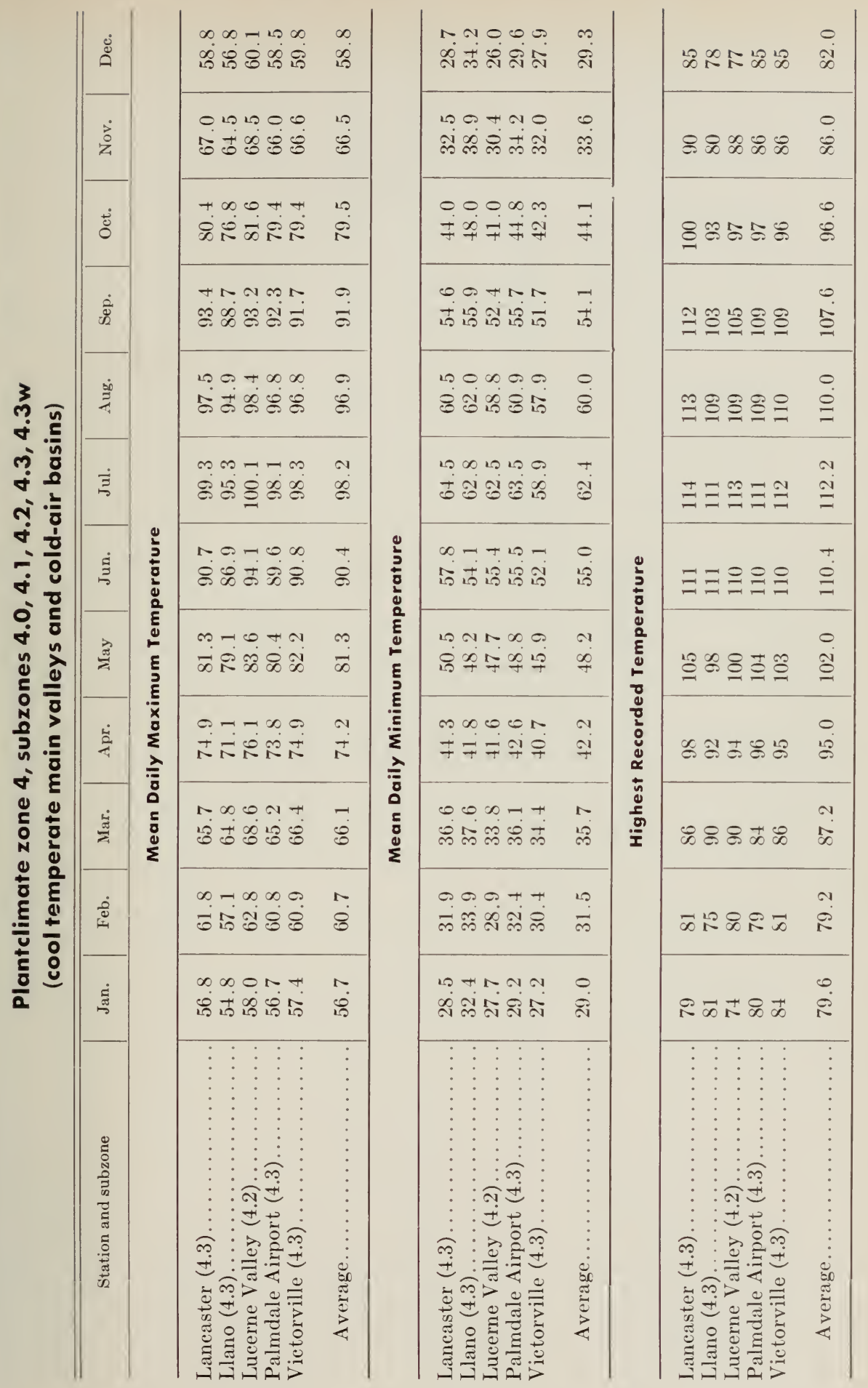




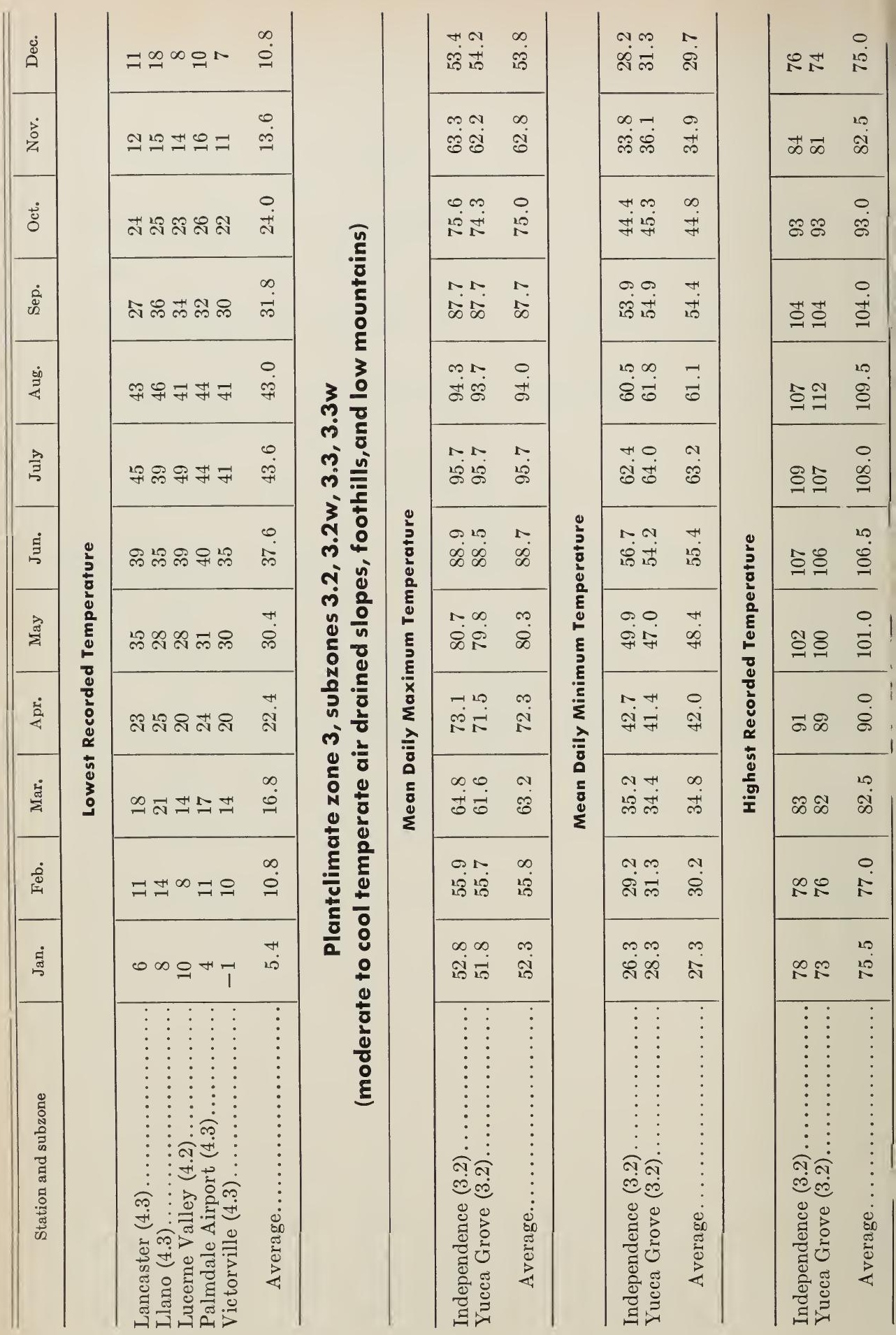




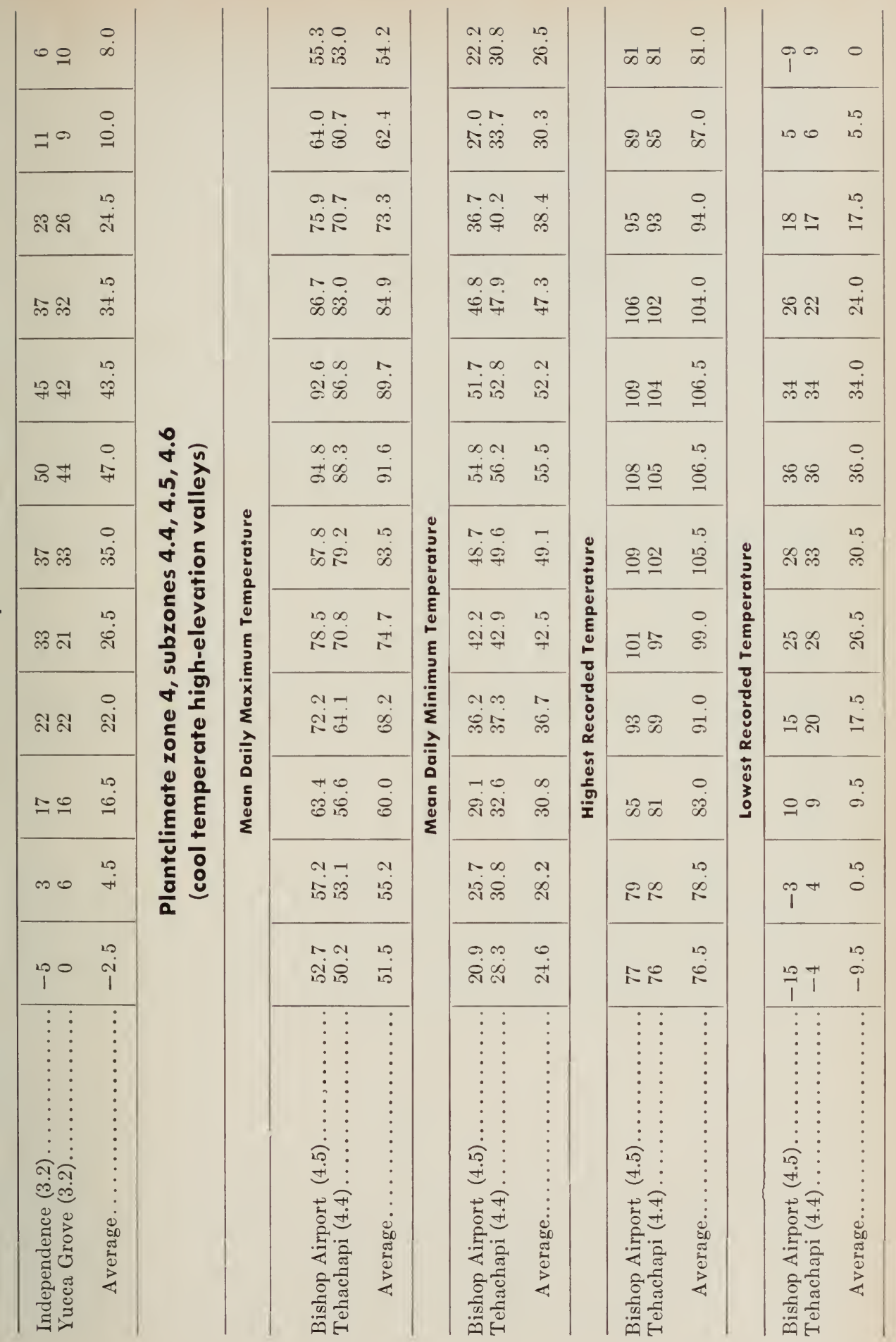




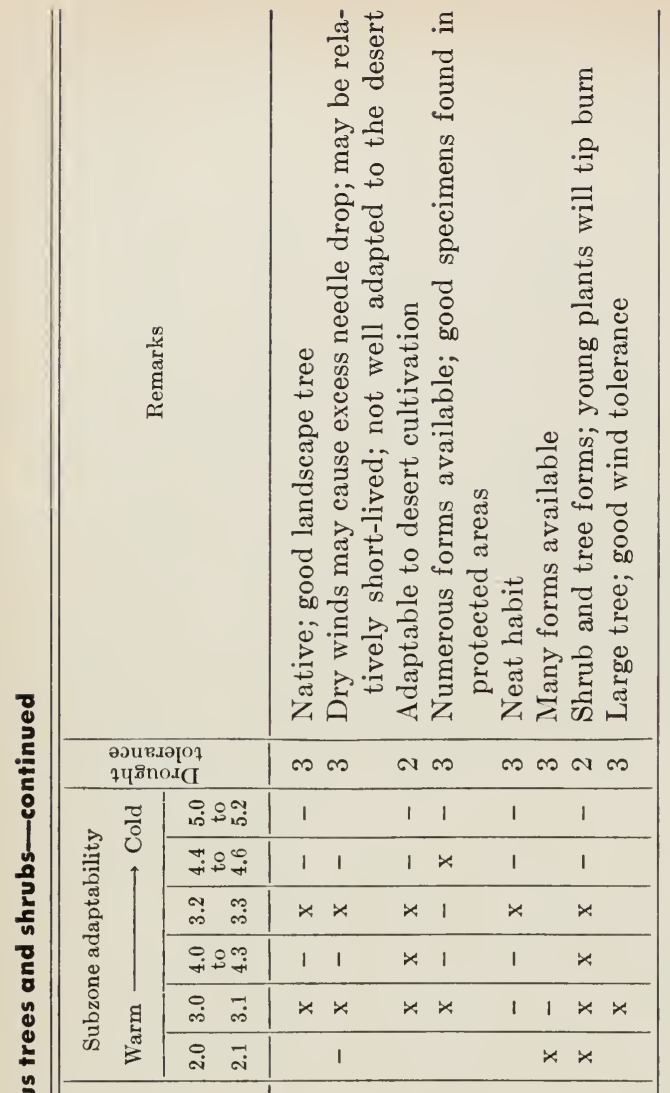

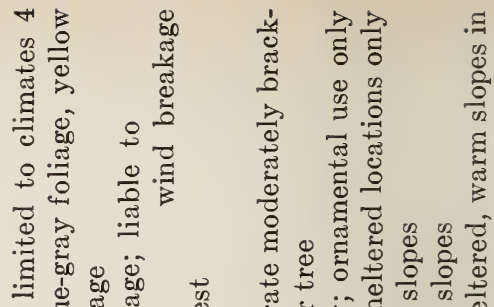
w

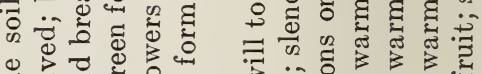

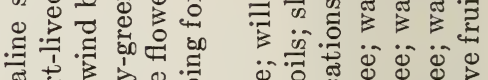

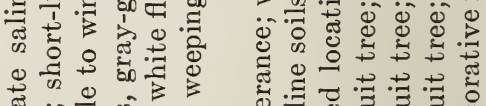

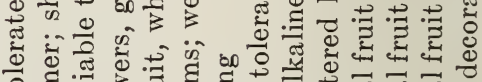
영

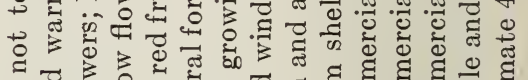
స హี

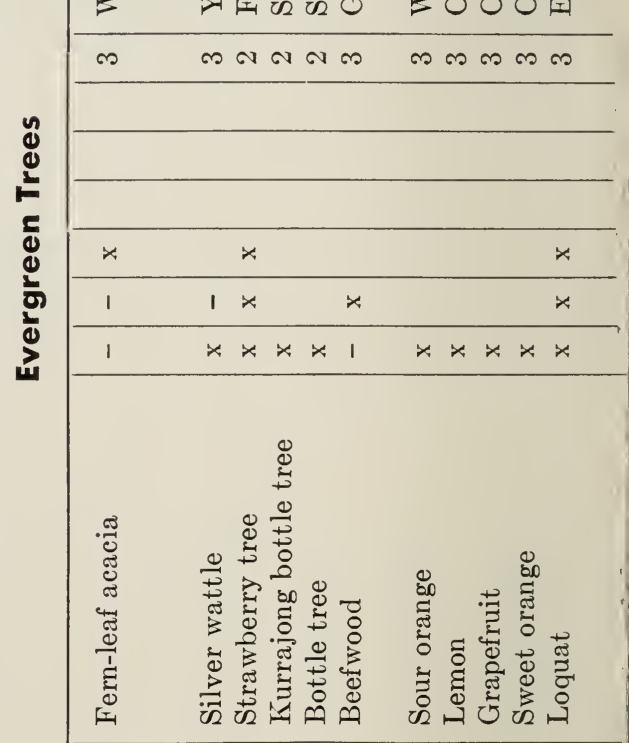

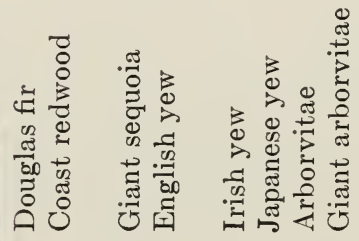

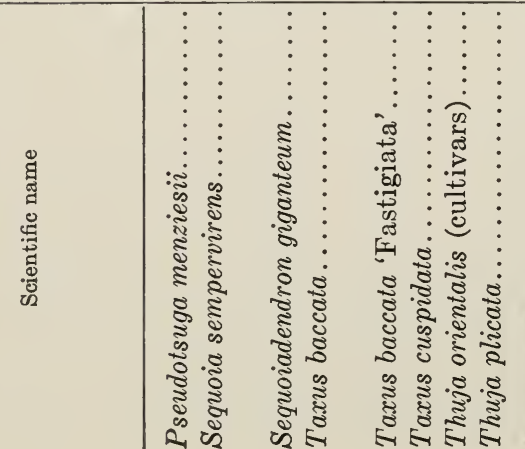

(2) 


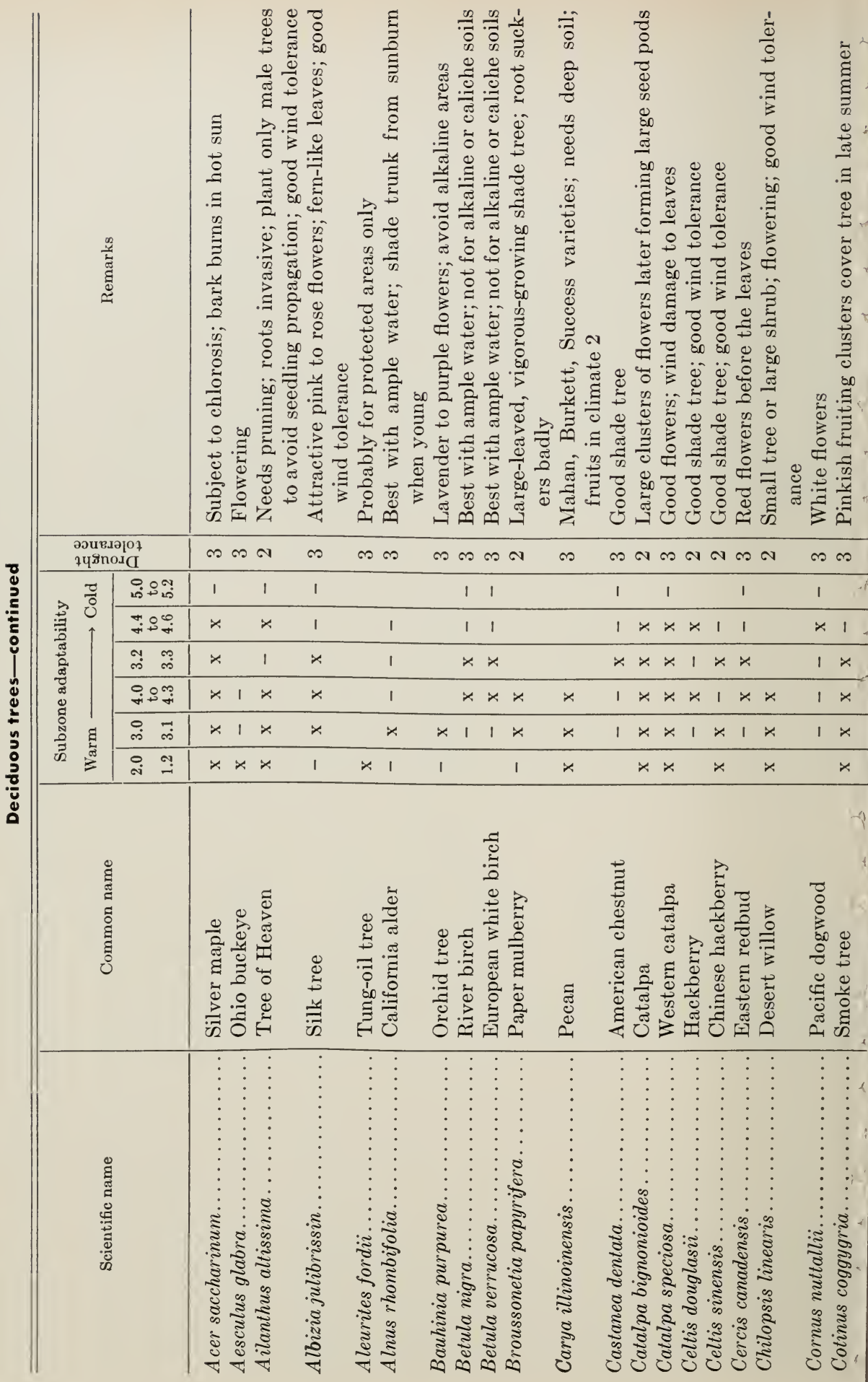


:

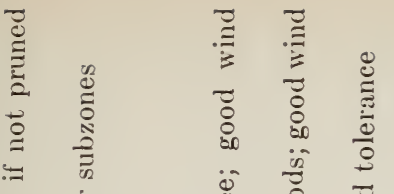

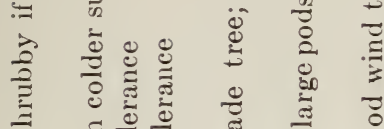

表

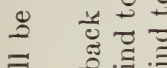

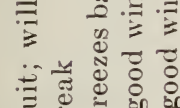

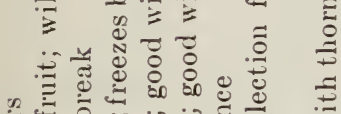

年

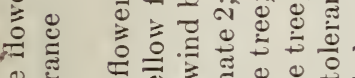

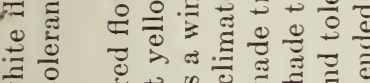

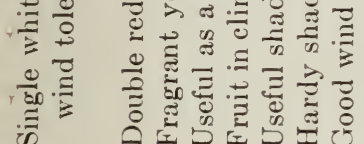

跣

$\infty$

ल M

童

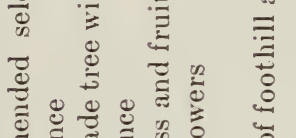

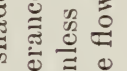

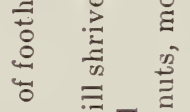

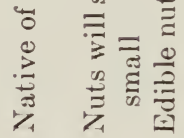

ข

1

$m$

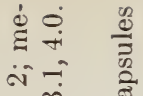

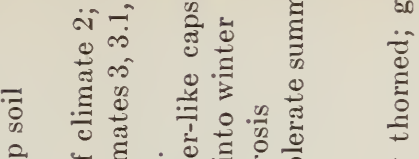

额

罂.

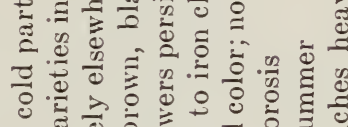

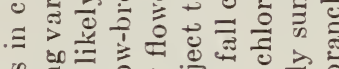

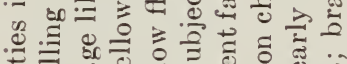

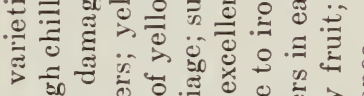
6o.

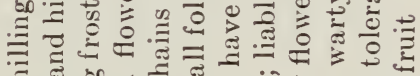

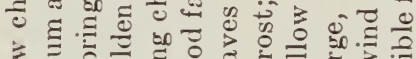

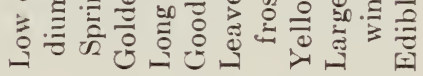

עח

$=x \times 1 \times 1 \times 1 \times 1 \times$

$x \mid x \times x \times 1 x x 1 x$

$x \times x \times 1 \times 1 \times 1 \times 1 \times 1 \times 1$
$11 x \times 1 \times 1$

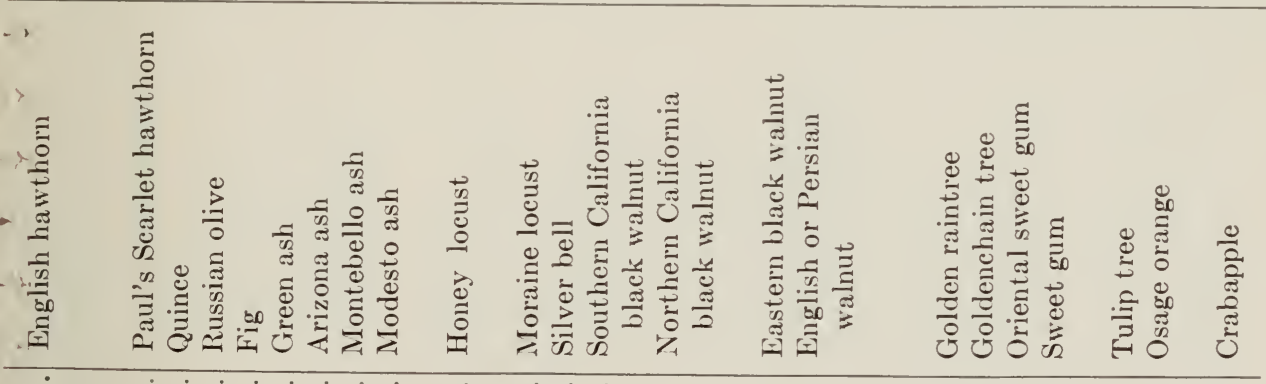

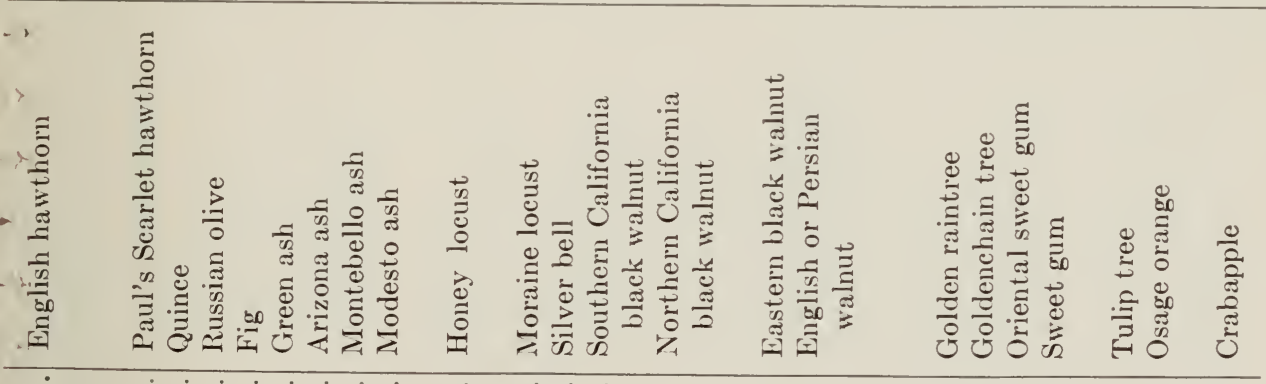

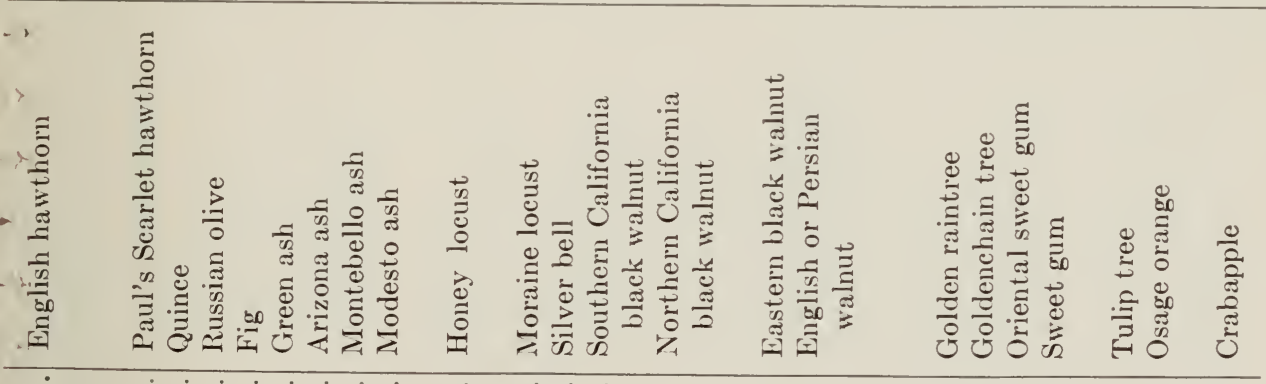

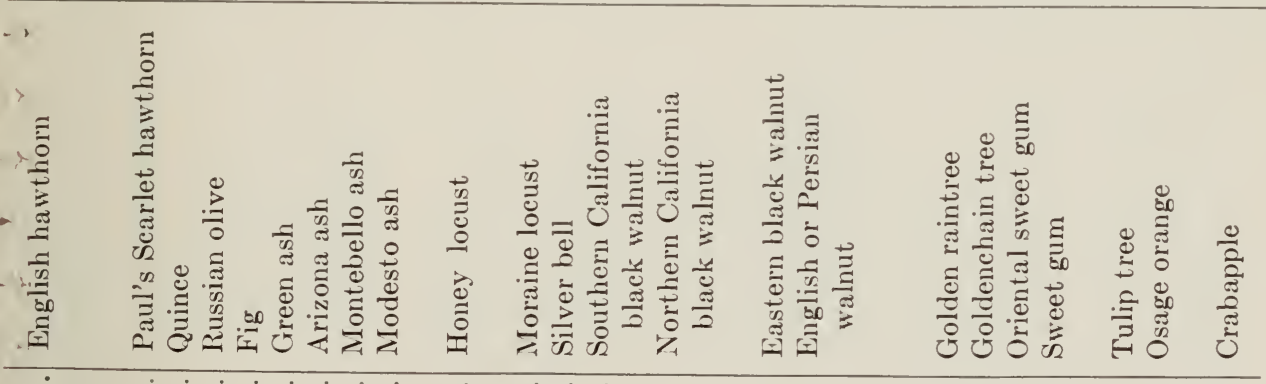

$x$

$x$

(1)

1

I 1

I

$\left(\frac{10}{2}\right.$

$x \quad 1 \quad 1 \quad 1$

$1 x$

1

$x$

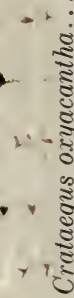

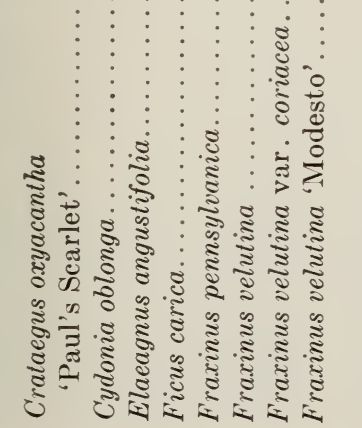

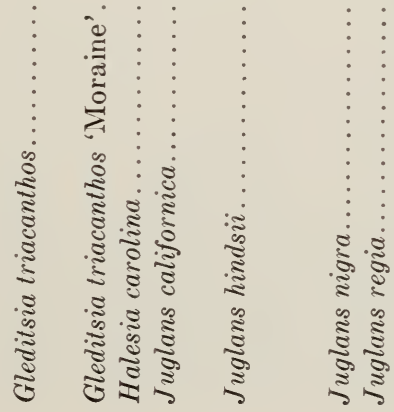

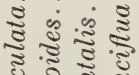

离

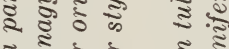

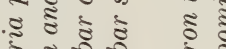

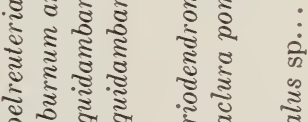

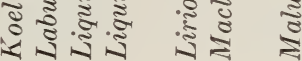




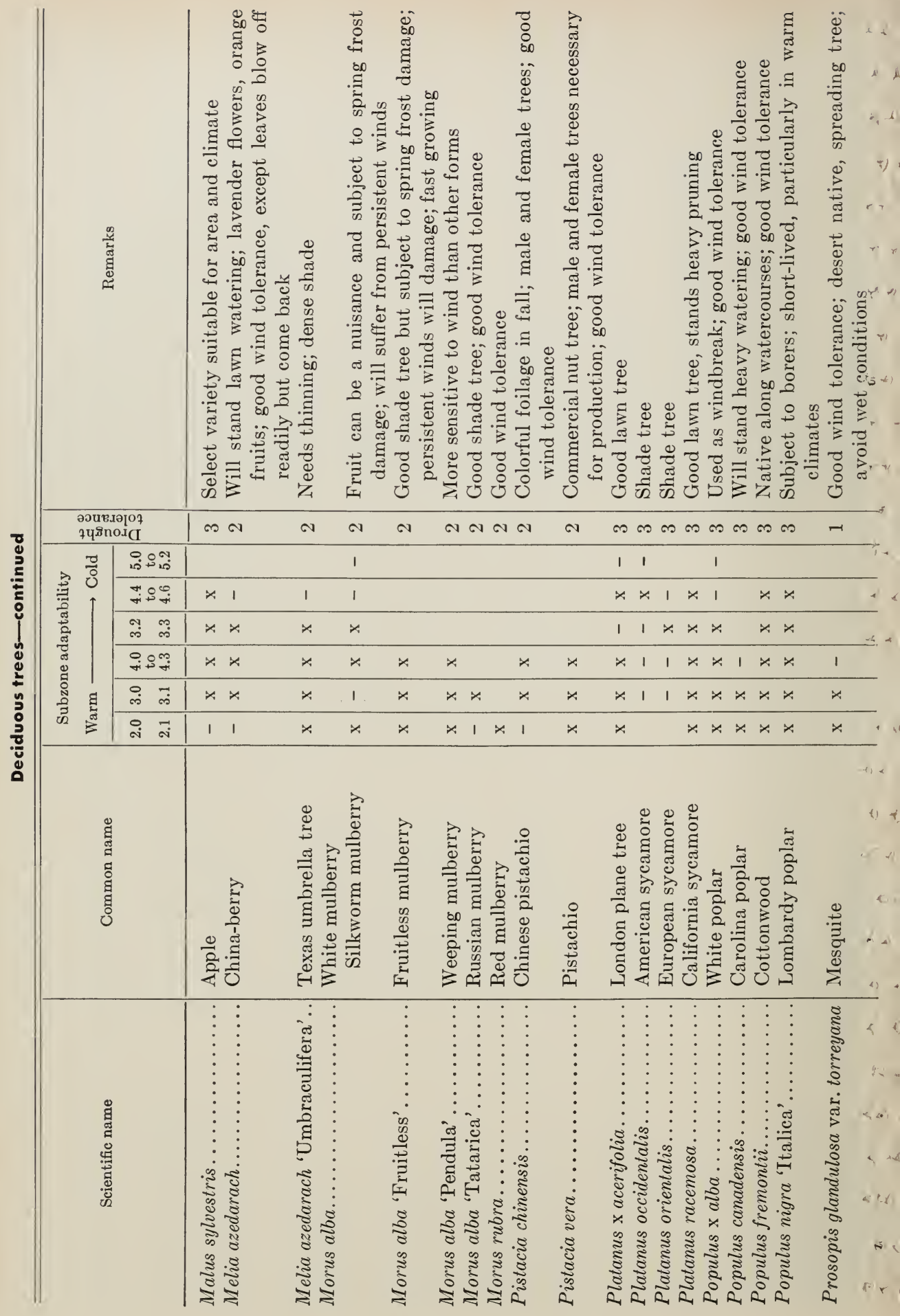




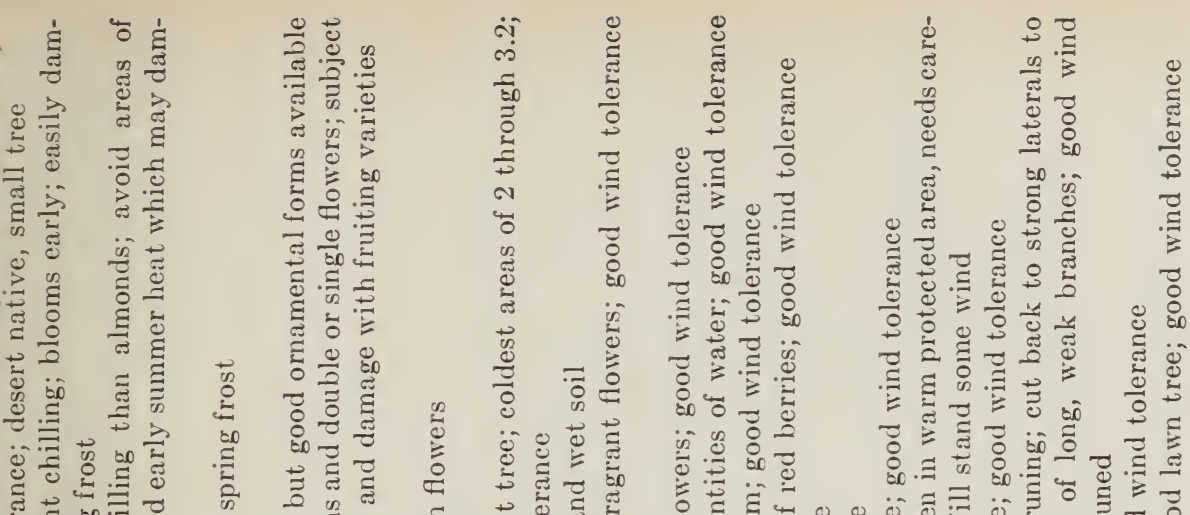

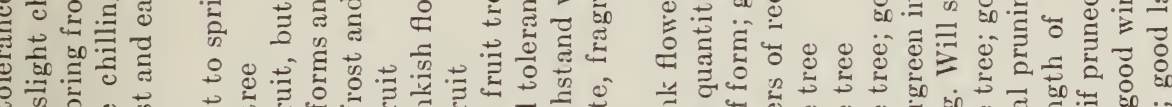

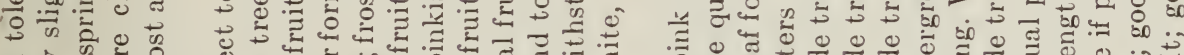

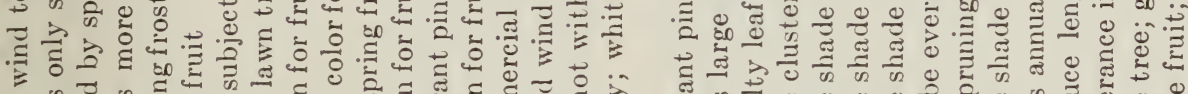

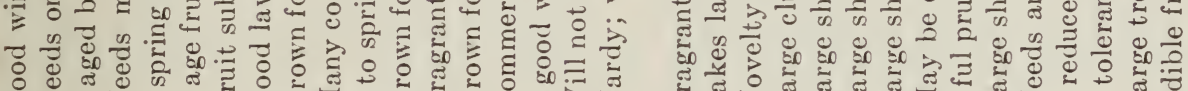
ن

na n

$1 \times 1 \quad 1 \quad 1 \quad 1 \quad 1 \times 1 \times 1 \times 1 \times 1 \quad 1 \times$

।

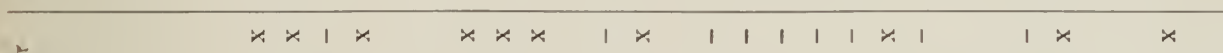

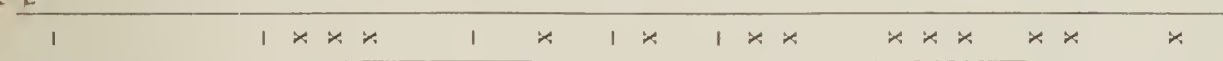

\begin{tabular}{|c|c|c|c|c|c|c|c|c|c|c|c|c|c|c|c|c|c|c|c|c|c|}
\hline I & $x$ & $x$ & $r$ & $x$ & $x$ & $x$ & 1 & I & $x$ & $x$ & $x$ & $x$ & $x$ & $x$ & $x$ & $x$ & 1 & $x$ & 1 & $x$ & $x$ \\
\hline$x$ & $x$ & $x$ & $x$ & $x$ & & $x$ & $x$ & & $x$ & 1 & & $x$ & 1 & $x$ & 1 & $x$ & & $x$ & & $x$ & $x x$ \\
\hline
\end{tabular}

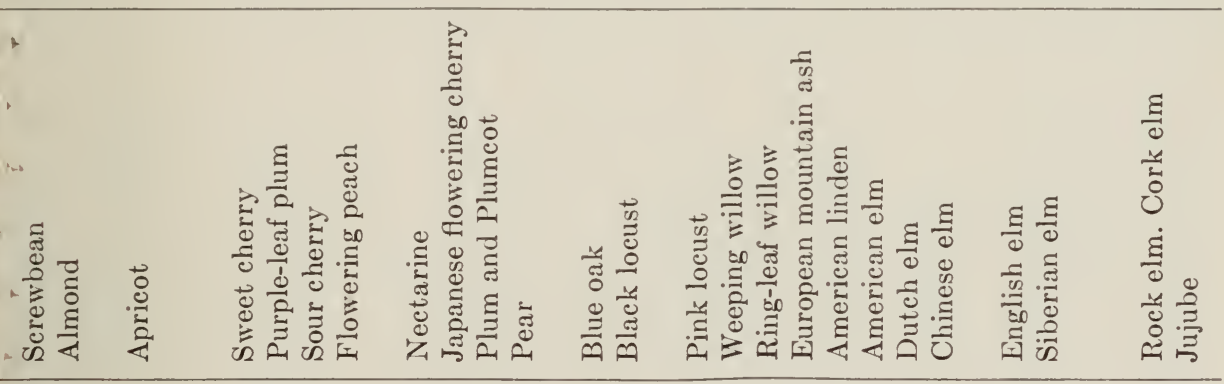




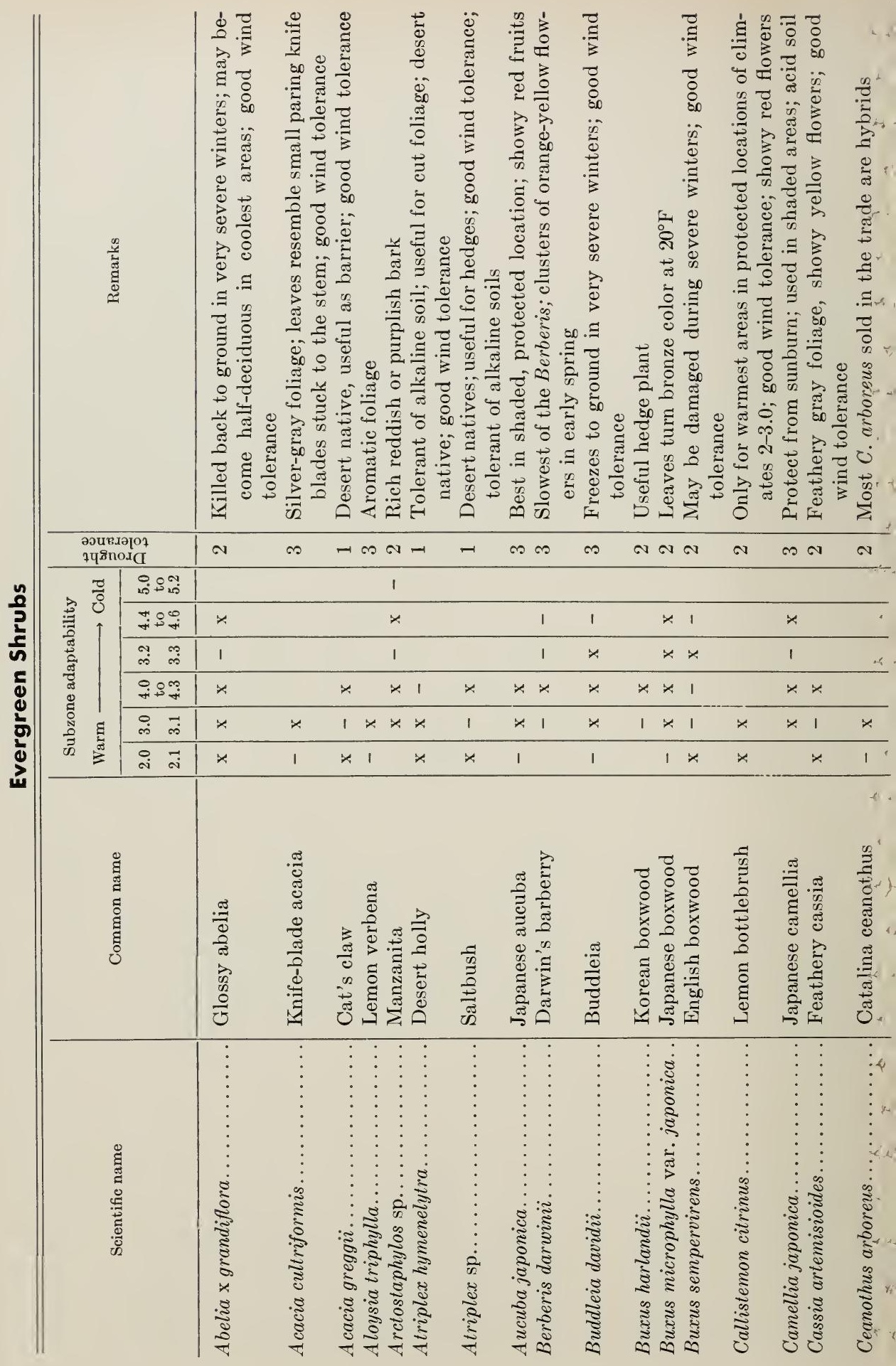




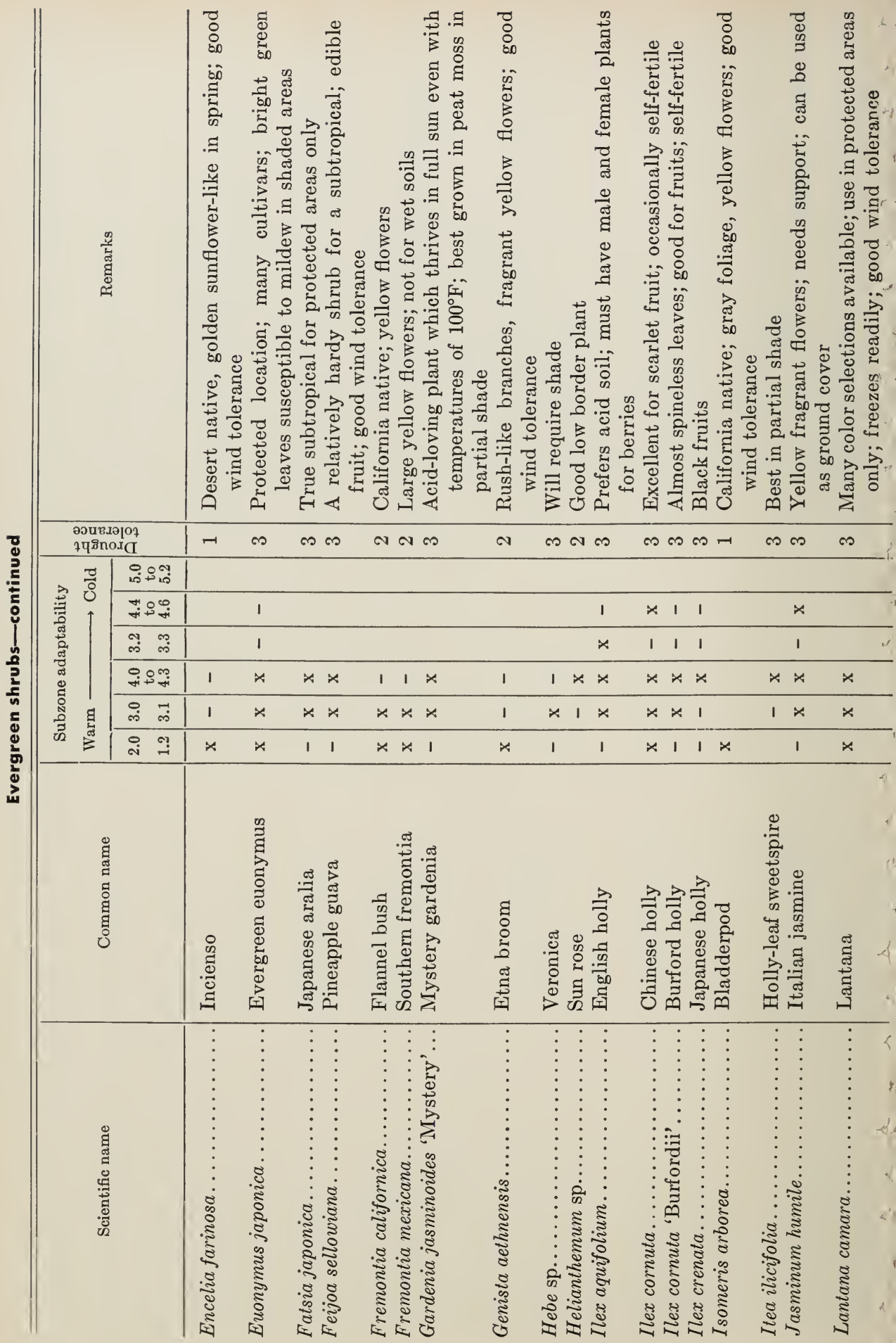




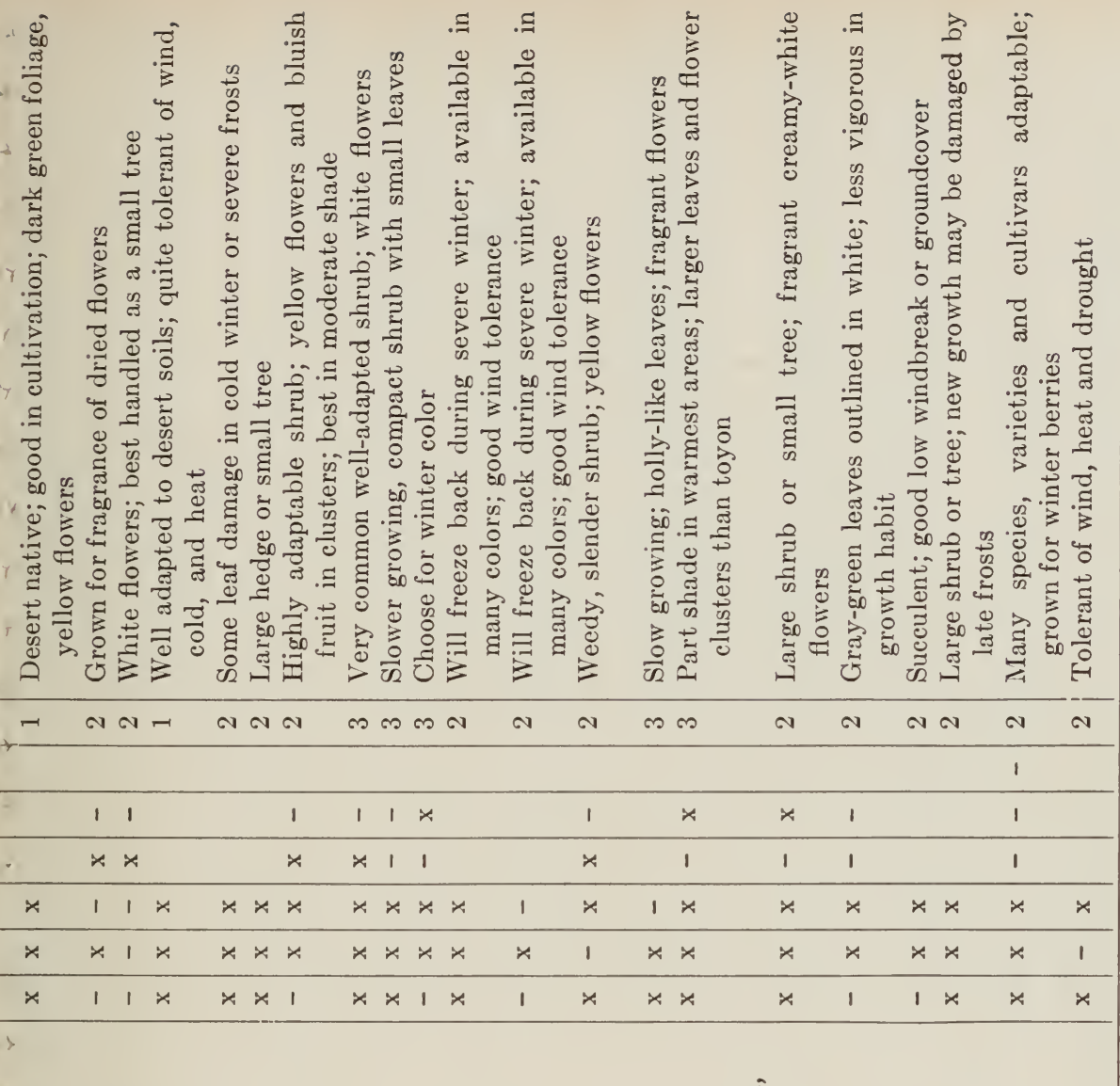

\begin{tabular}{|c|c|c|c|c|c|c|c|c|c|c|c|c|c|c|c|c|c|c|c|c|}
\hline 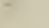 & 1 & 1 & & & & 1 & 1 & 1 & $x$ & & & I & & $x$ & $x$ & 1 & & & 1 & \\
\hline . & $x$ & $x$ & & & & $x$ & $x$ & 1 & 1 & & & $x$ & & 1 & 1 & 1 & & & 1 & \\
\hline$x$ & 1 & 1 & $x$ & $x$ & $x$ & $x$ & $x$ & $x$ & $x$ & $x$ & 1 & $x$ & 1 & $x$ & $x$ & $x$ & $x$ & $x$ & $x$ & $x$ \\
\hline$x$ & $x$ & 1 & $x$ & $x$ & $x$ & $x$ & $x$ & $x$ & $x$ & $x$ & $x$ & 1 & $x$ & $x$ & $x$ & $x$ & $x$ & $x$ & $x$ & 1 \\
\hline$x$ & 1 & 1 & $x$ & $x$ & $x$ & 1 & $x$ & $x$ & 1 & $x$ & 1 & $x$ & $x$ & $x$ & $x$ & 1 & 1 & $x$ & $x$ & $x$ \\
\hline
\end{tabular}

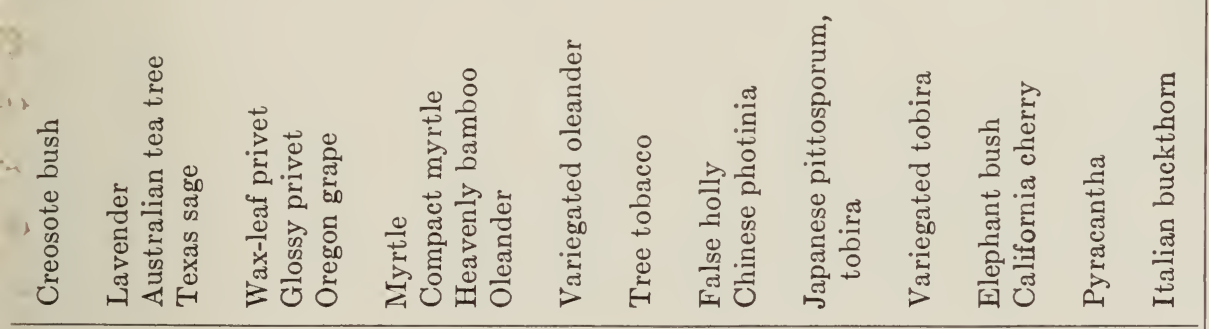

, 


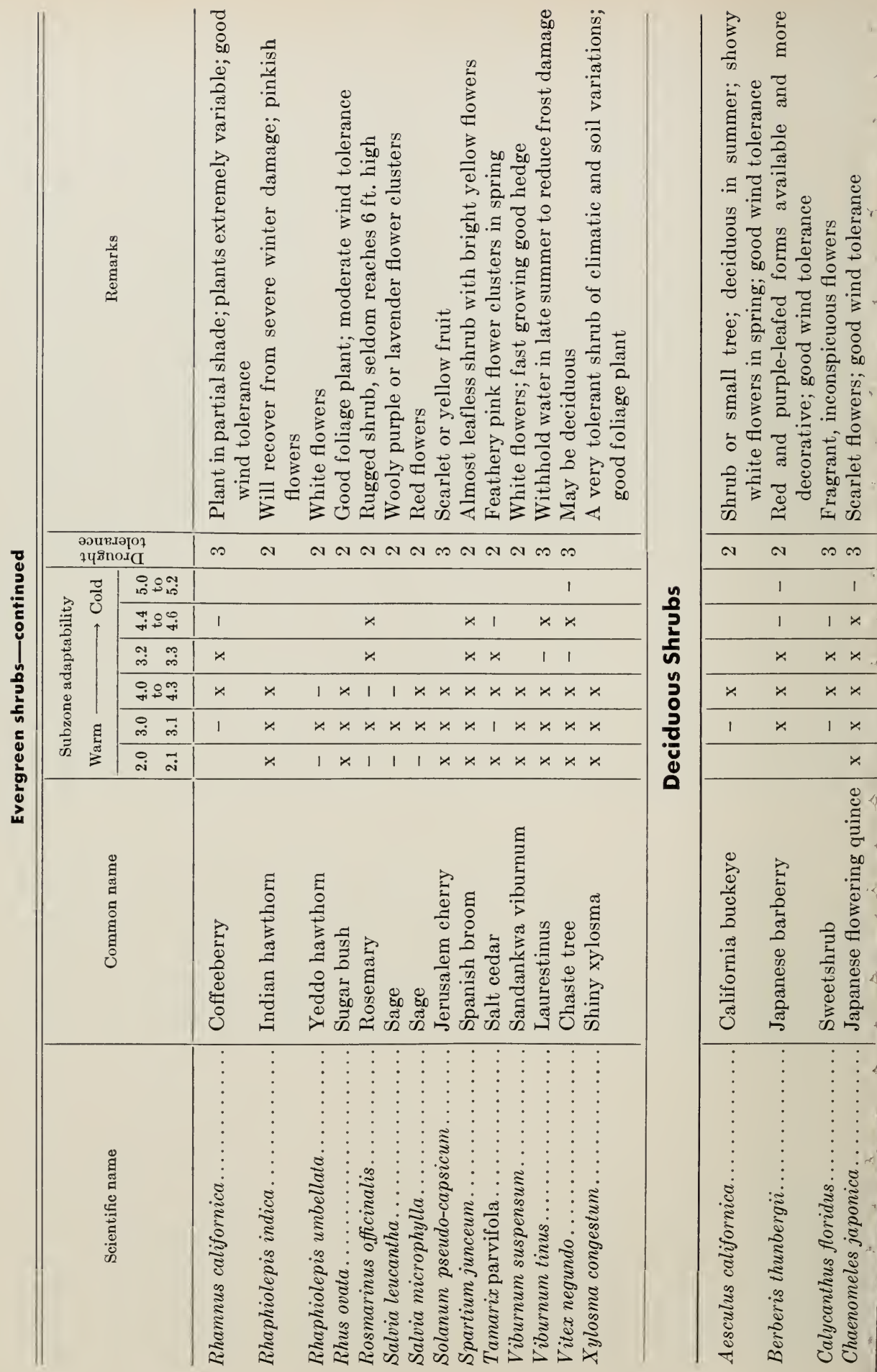




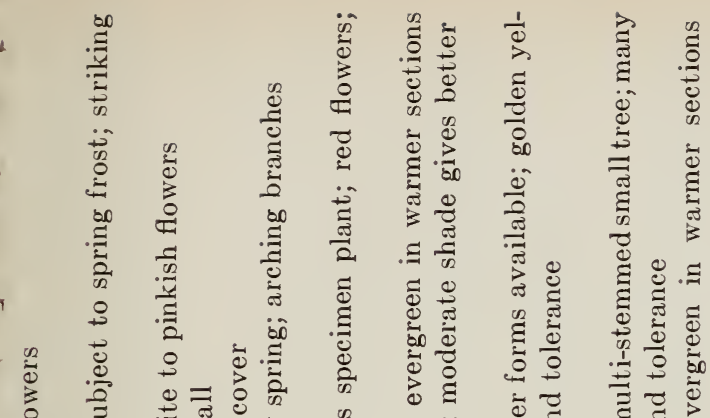

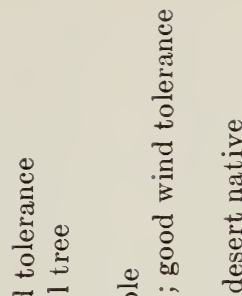

:

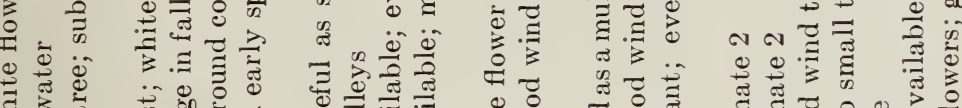

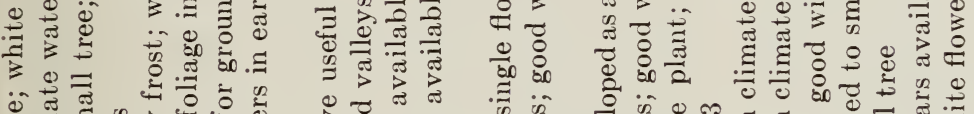

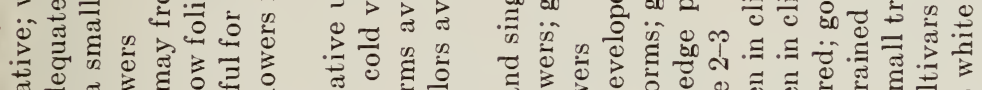

苛兽

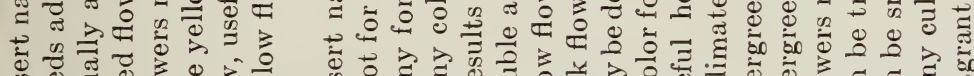

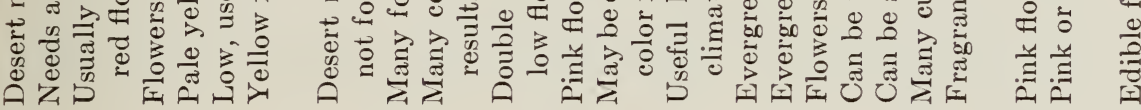

H

$x \quad 1 \quad x \times \quad x \quad x \quad x \quad x \quad 1 \quad 1 \times 1 \times 1 \times 1 \quad 1 \quad x \quad 1$

$11 \times 1 \times x \times x \quad x \quad 1 \quad x \quad x \quad \begin{array}{lllllllllll}1 & 1 & 1 & 1 & 1 & 1 & x & 1 & x\end{array}$

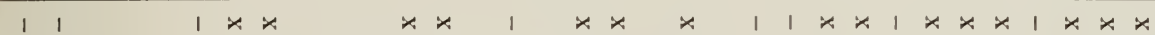

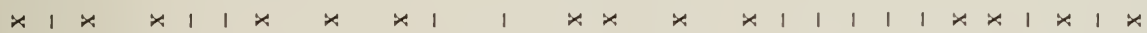

$\begin{array}{lllllllllllll}1 & 1 & x & 1 & 1 & 1 & 1 & 1 & x & 1 & 1 & x & 1\end{array}$

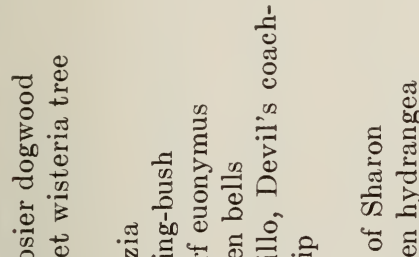

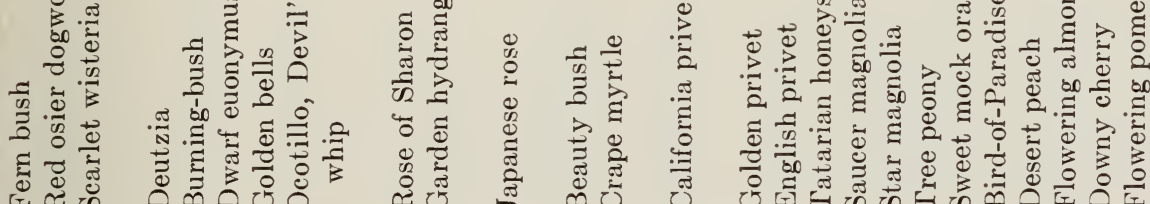

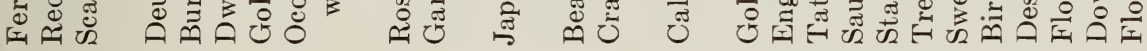

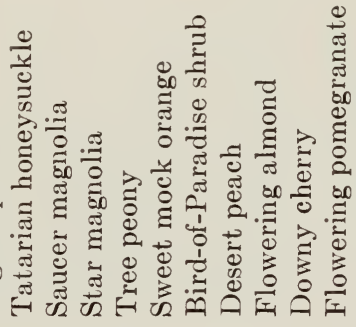

节

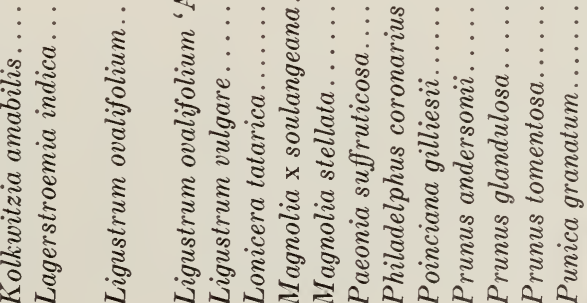




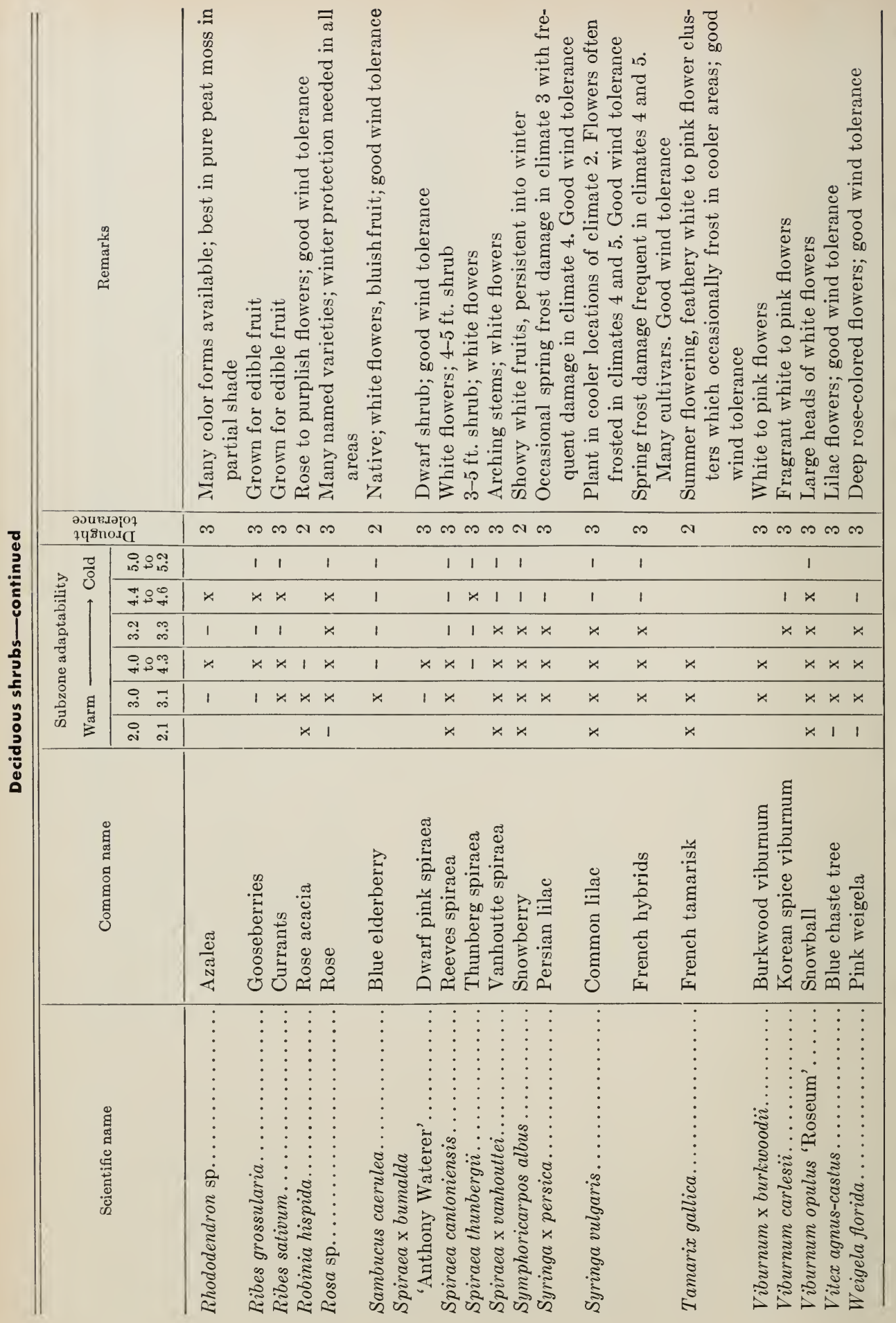




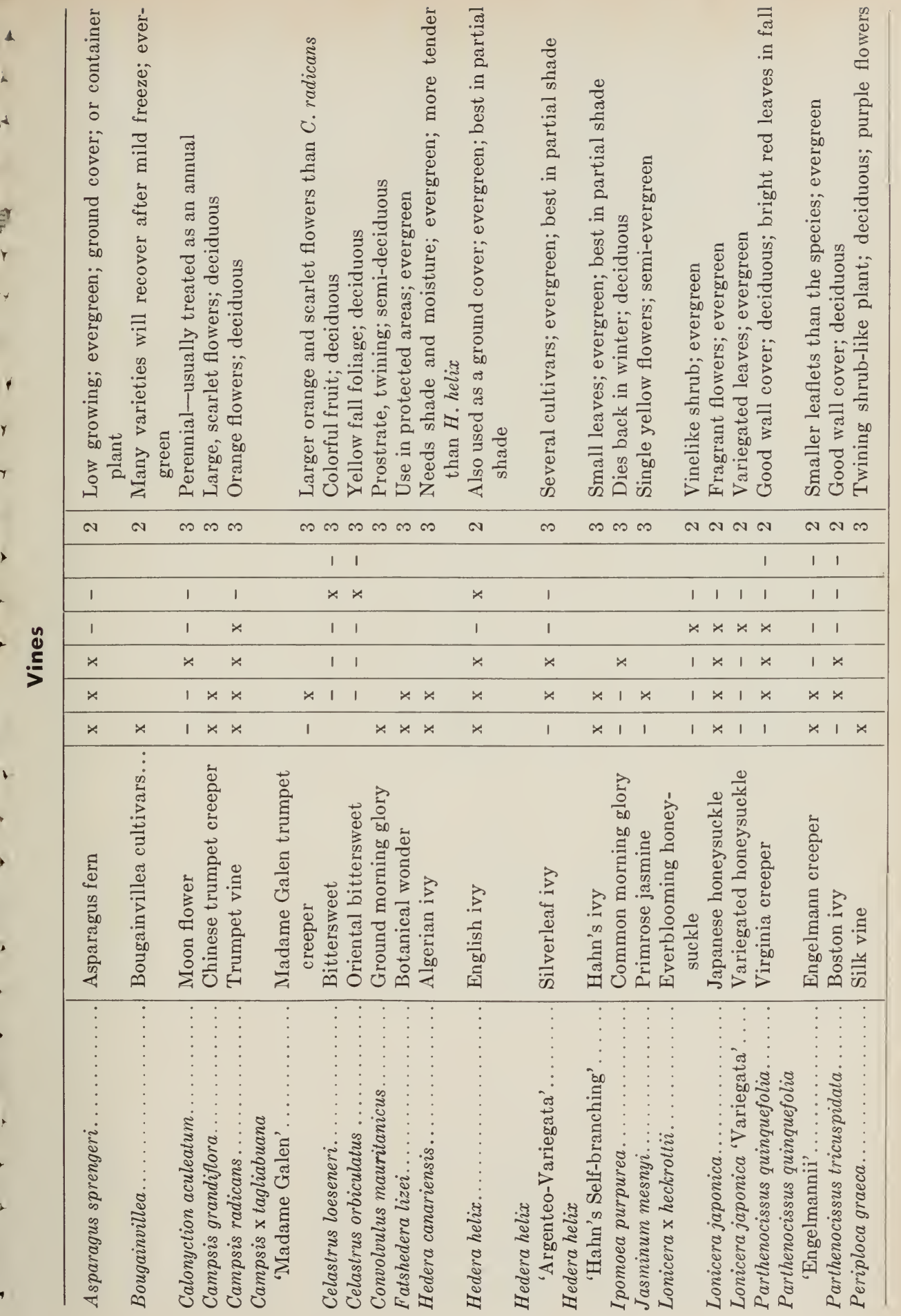




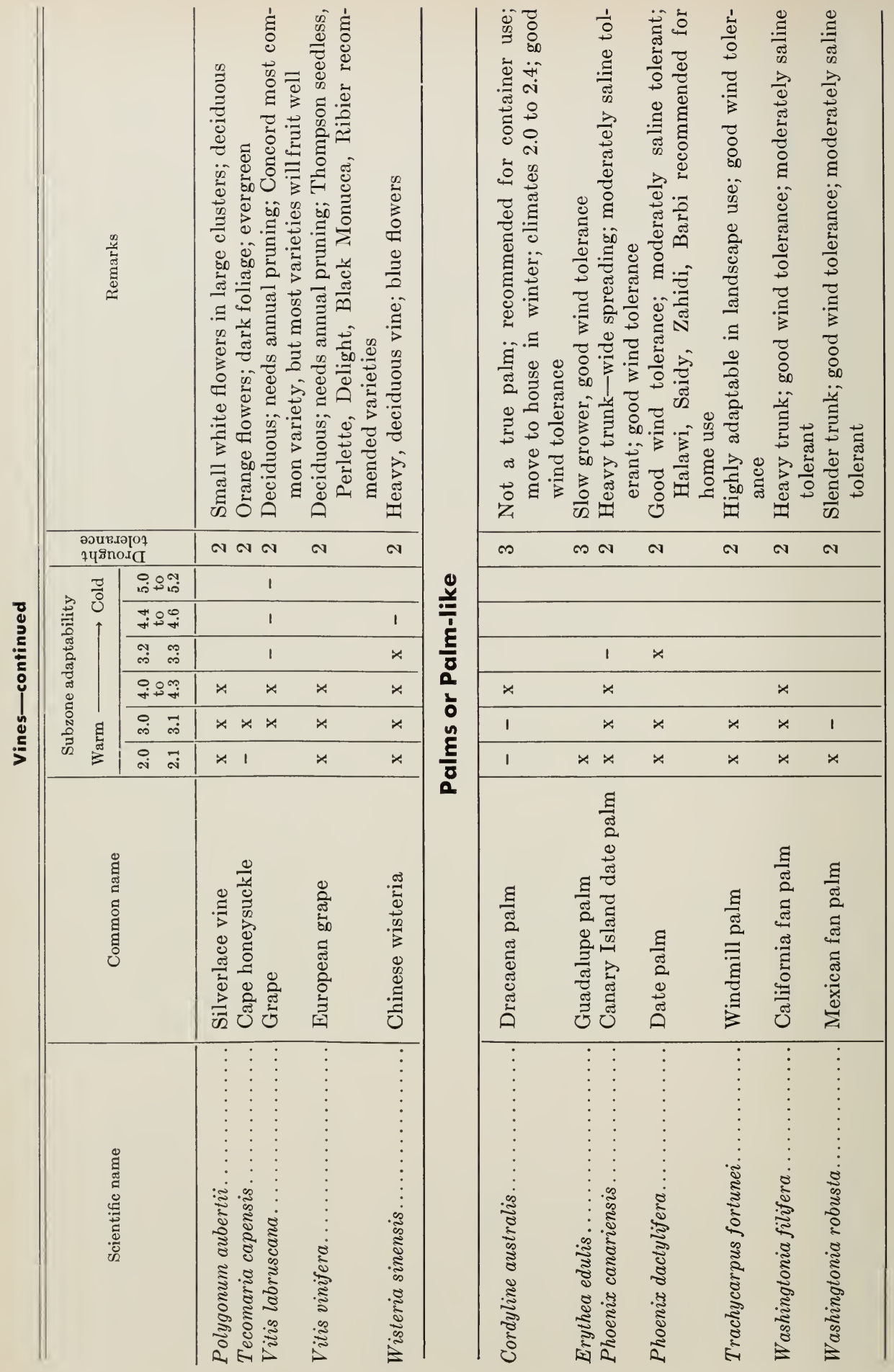




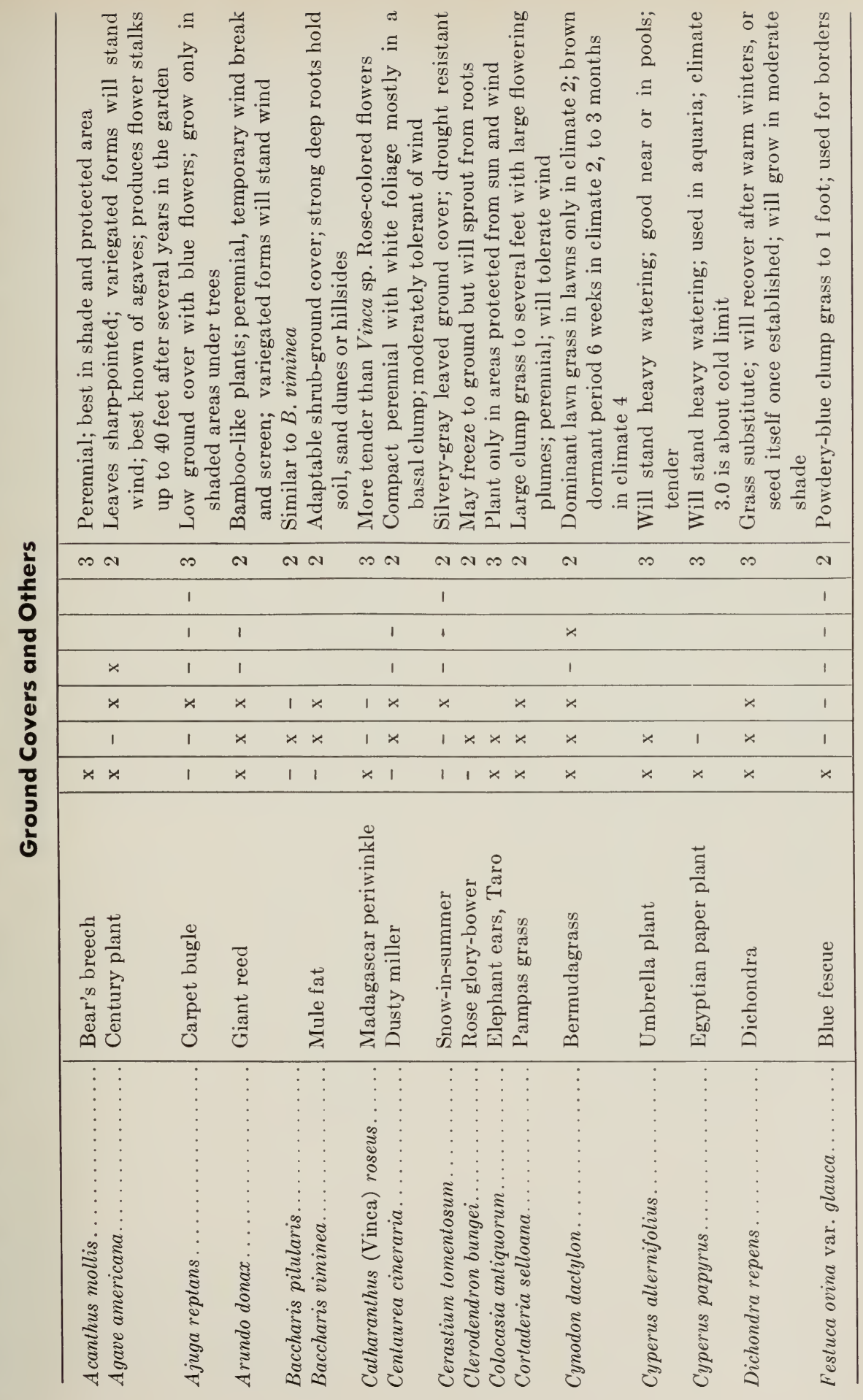




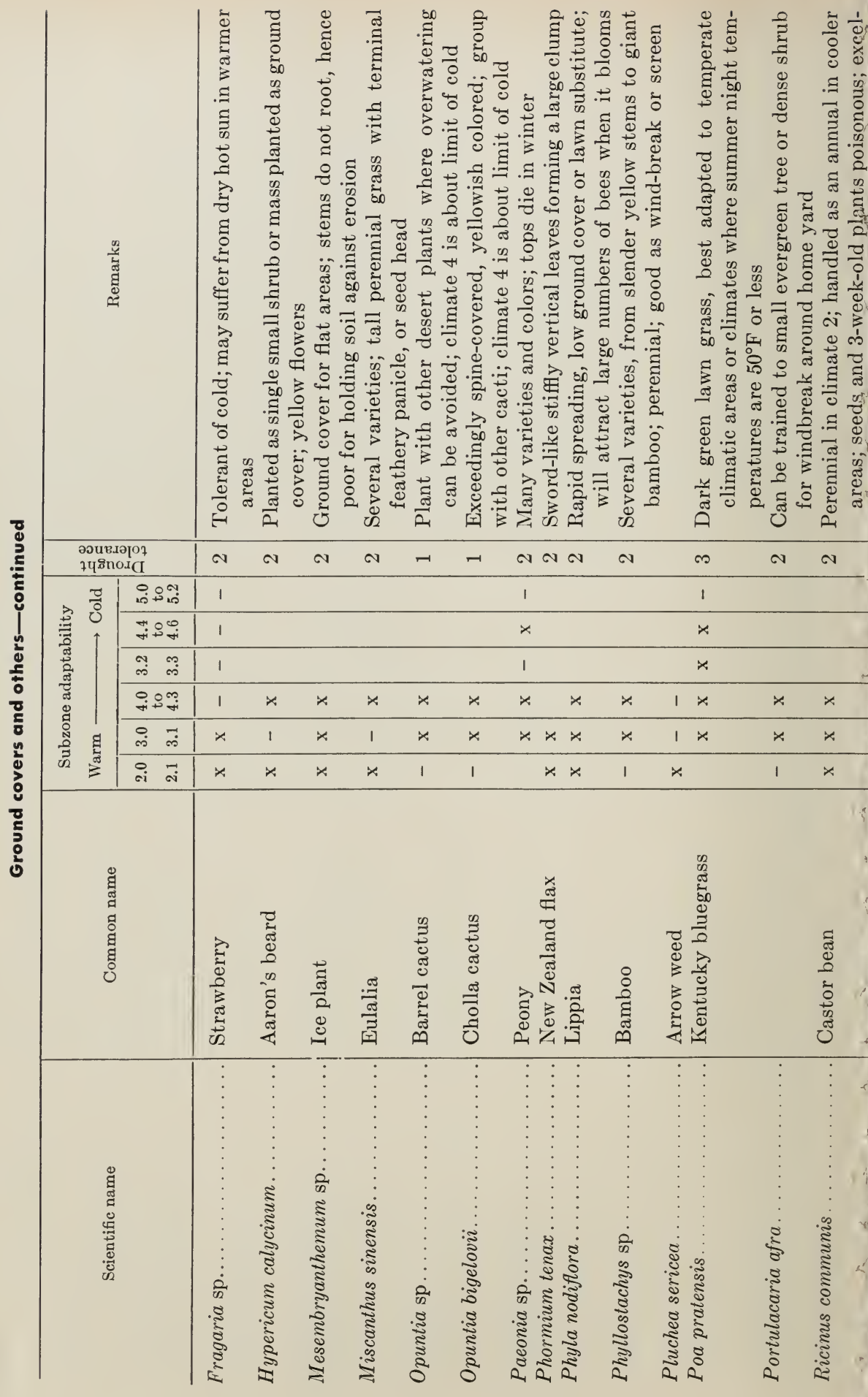




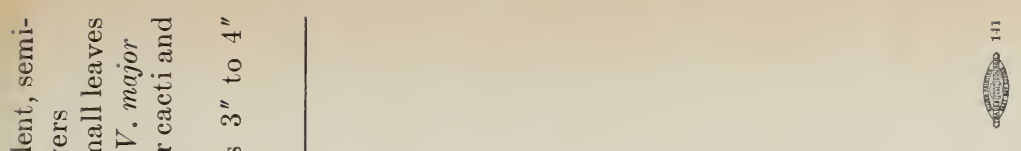

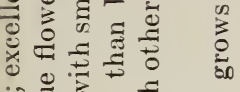
$\because \stackrel{0}{3}$.

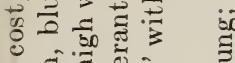

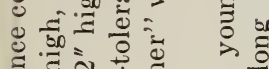

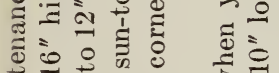

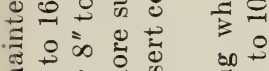

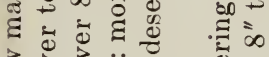

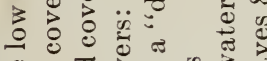

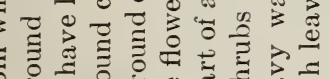

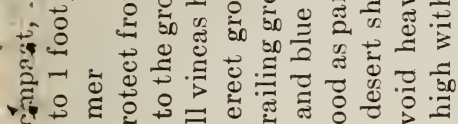

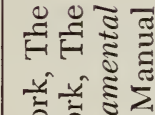

0
0
0

乙艺志跑

站芯芯

(2) 0

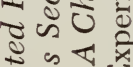

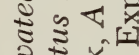

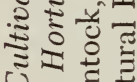

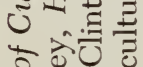

○े

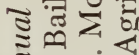

吾 $\mathrm{N}$ 되.

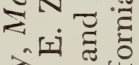

흃.

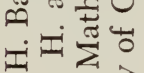

i $\dot{i} \dot{\Sigma}$

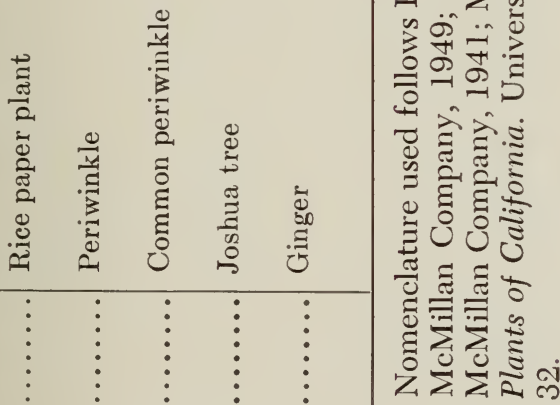

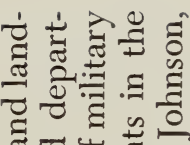

สี

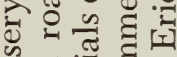

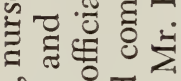

ญ्वิ

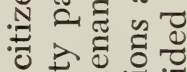

๙

施

$\sum$ हD류

(ปี ส ส

บิ

ए

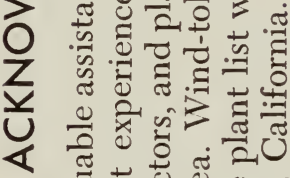

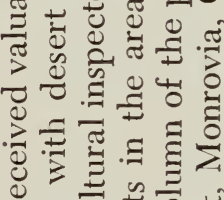

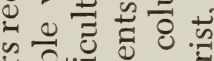

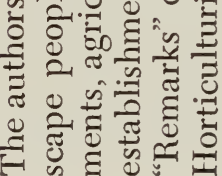




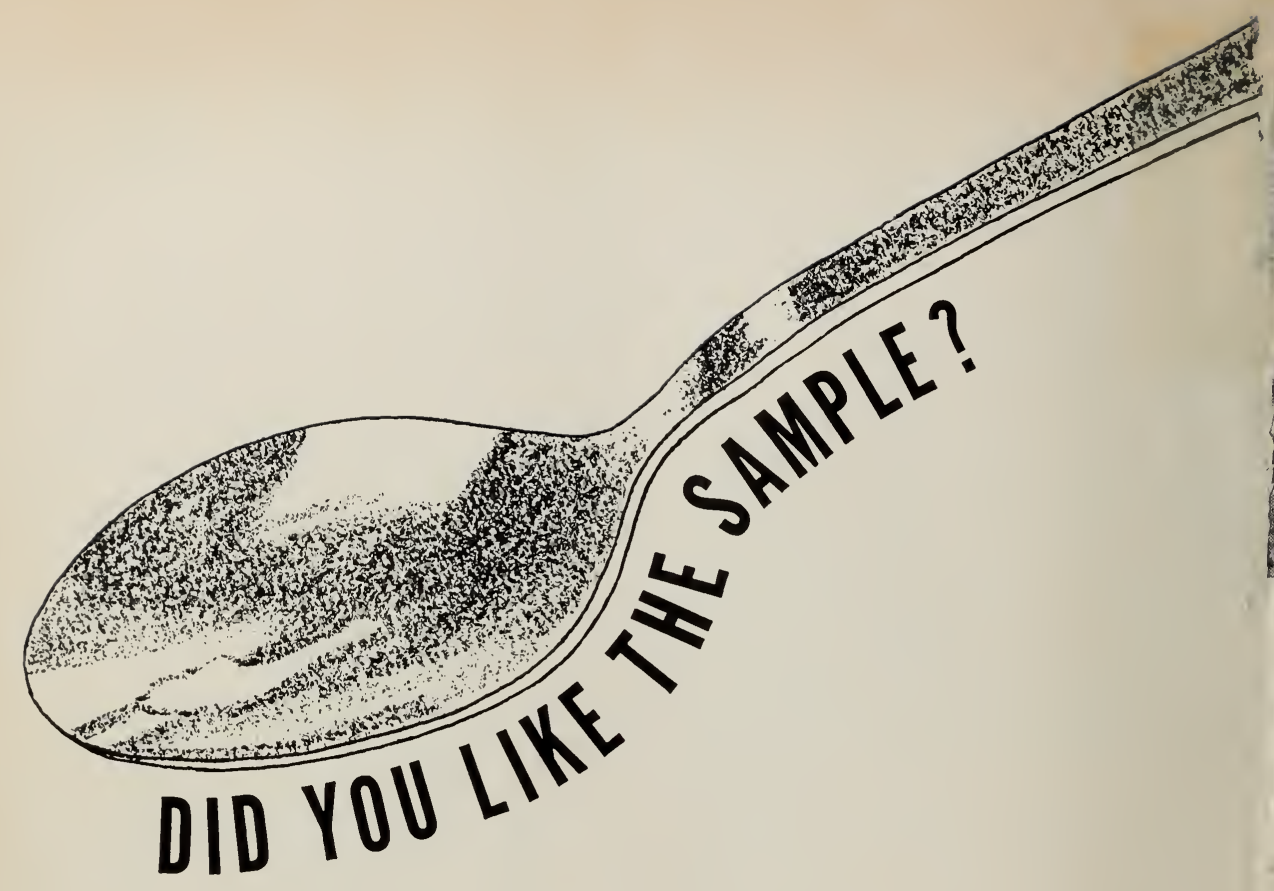

7 his publication is one of many that are written, produced, and distributed by the University of California Division of Agricultural Sciences.

$\boldsymbol{T}$ hey cover many subjects, from agronomy to zoology. They cover many crops, from alfalfa to zucchini.

Some report new research findings... some tell "how to do it."

Most are free... for some there is a charge.

All are listed in a catalog that is issued annually.

$\boldsymbol{T}$ o get a copy of the catalog, visit the office of your local University of California Farm Advisor, or write to:

Agricultural Publications University Hall University of California Berkeley, Calif. 94720 